Review Paper

\title{
Ionic liquid assisted synthesis of six-membered oxygen heterocycles
}

\author{
Navjeet Kaur ${ }^{1}$ \\ (c) Springer Nature Switzerland AG 2019
}

\begin{abstract}
Due to special properties of ionic liquids (ILs) like their wide liquid range, good solvating ability, negligible vapour pressure, non-inflammability, environment friendly medium, high thermal stability, easy recycling and rate promoters etc. they are used in organic synthesis. The investigation for replacement of organic solvents in organic synthesis is a growing area of interest due to increasing environmental issues. Therefore, ILs have attracted the attention of chemists and act as catalyst and reaction medium in organic reaction with high activity. There is no doubt that ILs have become a major subject of study for modern chemistry. In comparison to traditional processes the use of ILs resulted in improved, complimentary or alternative selectivities in organic synthesis. The aim of present review is to focus on the applications of ILs for the synthesis of six-membered oxygen heterocycles (pyrans, chromenes, coumarins and dioxanes).
\end{abstract}

Keywords Ionic liquid · Oxygen · Heterocycles

\section{Introduction}

Heterocyclic compounds possess many biological activities. Various natural products (hormones, vitamins, alkaloids and antibiotics), herbicides, pharmaceuticals and dyes are constituted by heterocycles [1-64]. In the past few decades, researchers have paid their much attention to explore efficient and new synthetic strategies for the preparation of heterocycles due to a wide range of applications associated them [65-97]. Among these synthetic protocols ionic liquid assisted methods gained much attention due to their short reaction times, mild reaction conditions and improved yield. More green and environmentally benign synthetic procedures are highly recommended for the organic synthesis. In the past few years, the utilization of ionic liquids in place of conventional organic solvents have much significance [98-102]. The effectiveness of synthetic route is not only measured by parameters such as yield and selectivity, but other factors like time, raw material, human resources, hazard and toxicity of the chemicals and energy consumption are also considered. The use of ionic liquids in multi-component reactions not only provided the environmentally benign reaction medium, but ILs also act as catalyst, which is an added advantage [103-109]. Ionic liquids, due to their non-flammable, non-volatile, thermal stability, solvating potential and recyclable features, are favorable medium for chemical syntheses and have replaced traditional organic solvents [110-120].

Only ions are possessed by an IL. Room-temperature ionic liquids (RT ILs) contain asymmetric and bulky organic cations like 1-alkylpyridinium, 1-alkyl-3-methylimidazolium, ammonium ions or 1-methyl-1-alkylpyrrolidinium (Fig. 1). Ionic liquids carry a variety of anions such as simple halides, large organic anions i.e. tosylate or triflate, bis(trifluorosulfonyl)amide and inorganic anions like hexafluorophosphate and tetrafluoroborate (Fig. 2) [121-126].

Nowadays, it is known that some properties of anions influence more dramatically the intrinsic cytotoxicity of ionic liquids. Anions quite lipophilic and/or unstable were reported to play a major role. The most important function of ionic liquid is to stabilize the charged activated complex through solvent-solute-type interactions, similar (but not identical) to the interaction between polar protic/aprotic solvents and solutes [127-130].

\footnotetext{
Navjeet Kaur, nvjithaans@gmail.com | 'Department of Chemistry, Banasthali Vidyapith, Banasthali, Rajasthan 304022, India.
} 
Fig. 1 Cations of ionic liquids<smiles>[R][n+]1ccccc1</smiles><smiles>[R]n1cc[n+]([R])c1</smiles><smiles>[R]n1c[n+]([R])cn1</smiles><smiles>[R2][N+]1([R1])CCCC1</smiles><smiles>[R][N+]([R7])([R1])[R1]</smiles><smiles>[R][P+]([R7])([R7])[R7]</smiles><smiles>[R12][14C]([Y20])=[NH2+]</smiles>

\section{Cations}

Ionic liquids are often deemed to have high thermal and chemical stability, and wide electrochemical window. However, this is not always true because the stabilities of various ionic liquids are very different. The instabilities of ionic liquids should come from the complex molecular structures. The stability of ionic liquids mainly depends on their intrinsic composition, (cation and anion), and the interactions between anions and cations. However, different types of stabilities (thermal, electrochemical, and radiolytic) follow different rules because they cause unstable or decomposition by different mechanisms [131, 132].

Reports have suggested that ionic liquids are used in many fields especially in organic syntheses. The mechanism of working of ionic liquids in organic reactions is not known and it is a point of controversy among chemists. In organic reactions the catalyst/solvent effect of ionic liquids cannot be explained on the basis of data available on properties like polarity, dielectric constants, etc. Their high polarity and the ability to solubilize both inorganic and organic compounds can result in enhanced rates of chemical processes and can provide higher selectivities when compared to conventional solvents. Given their structure and the diversity of their functionality, they are capable of most types of interactions (e.g., dispersive, $\pi-\pi, n-\pi$, hydrogen-bonding, dipolar, and ionic/charge-charge). Various single-parameter polarity scales are essentially weighted averages of all possible solute-solvent interactions. Since ionic liquids are much more complex solvent systems capable of undergoing many types of interactions, characterizing them with a single polarity term fails to encompass the broad spectrum of types and the magnitude of individual interactions that make each ionic liquid unique. lonic liquids exhibit multiple behaviors, which explains why many ionic liquids act as polar solvents in organic reactions containing polar molecules and as less polar solvents in the presence of less polar molecules [133-139].

Some researchers have described that ionic liquids served as organocatalysts. This organocatalysis occurred through hydrogen bonding interactions; the results have demonstrated that they have a huge impact on organocatalysis. The use of ionic liquids in most powerful way is their use as a combination of catalyst and solvent in catalysis. The new solvent is employed as a catalyst if the change of solvent results in fast rate of reaction. Based on this idea the same solvent is kept in case of accelerated reaction. The features of ionic liquid solvents are studied in many studies. Different methods have provided a much data on properties of ionic liquids like polarity and dielectric constants. The ionic liquid, whose anion or cation acts as a catalyst activator, catalyst, or co-catalyst in a chemical reaction, is significant. In recent literature, the ionic liquid is prepared so that its one of the ion can act as a catalyst and reaction medium in reaction [140-151].

The purpose of this review is to discuss the recent and current applications of ionic liquids as solvents, catalysts and reaction media for the synthesis of six-membered oxygen heterocycles (pyrans, chromenes, coumarins and dioxanes).

\section{Ionic-liquid assisted synthesis of six-membered oxygen heterocycles (pyrans, chromenes, coumarins and dioxanes)}

\subsection{Synthesis of six-membered one oxygen containing heterocycles}

Song and co-workers $[152,153]$ synthesized 4H-pyrans in aminofunctionalized ionic liquids via catalytic protocol. A higher loading capacity was achieved when the reactions were conducted in homogeneous solutions because of lower molecular weight of the functionalized IL. The intermediates were purified by simple extraction. Due to hydrogen bonding, the miscibility and solubility properties of ionic liquid [2-aemim] $\left[\mathrm{PF}_{6}\right]$ (1-aminoethyl3-methylimidazolium hexafluorophosphate) are different than those of conventional ionic liquids. The ionic liquid (solvent) and reactant were utilized in a molar ratio of 1:3 


$$
\begin{aligned}
& \begin{array}{llllllllllll}
\mathrm{Cl}^{-} & \mathrm{Br}^{-} & \mathrm{TsO}^{-} & \mathrm{BF}_{4}^{-} & \mathrm{PF}_{6}^{-} & \mathrm{CN}^{-} & \mathrm{N}_{3}^{-} & \mathrm{TfO}^{-} & \mathrm{Tf}_{2} \mathrm{~N}^{-} & (\mathrm{CN})_{2} \mathrm{~N}^{-} & \mathrm{AcO}^{-} & \mathrm{NO}_{3}^{-}
\end{array} \\
& \begin{array}{llllllll}
\mathrm{CF}_{3} \mathrm{CO}_{2}^{-} & \mathrm{ClO}_{4}^{-} & \mathrm{FeCl}_{4}^{-} & \mathrm{AlCl}_{4}^{-} & \mathrm{Al}_{2} \mathrm{Cl}_{7}^{-} & \mathrm{TiCl}_{6}{ }^{2-} & \mathrm{Alkyl} \mathrm{BF}_{3}^{-} & (\mathrm{Alkyl})_{3} \mathrm{PF}_{3}^{-}
\end{array}
\end{aligned}
$$

\section{Anions}<smiles>CCCCn1cc[n+](C)c1</smiles>

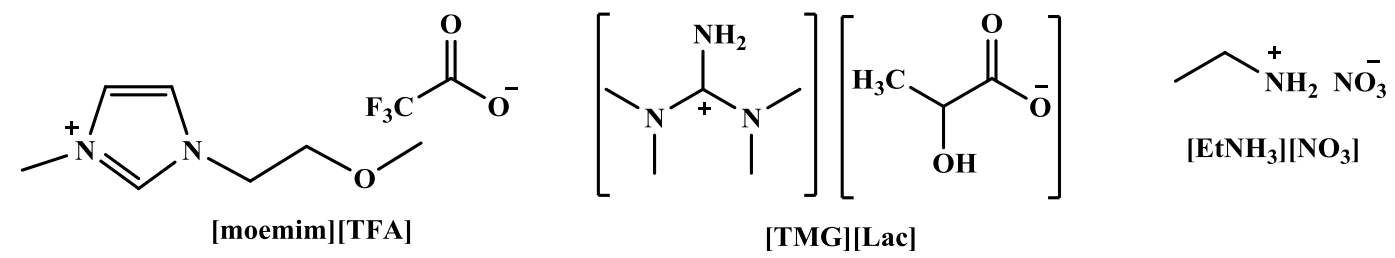<smiles>CCCCn1cc[n+](C)c1C</smiles>

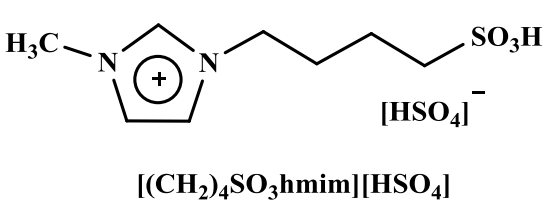<smiles>CCCC[N+]1(C)CCCC1</smiles>

[bmim $]\left[\mathrm{BF}_{4}\right]=1$-butyl-3-methylimidazolium tetrafluoroborate $[\mathrm{bmim}]\left[\mathrm{PF}_{6}\right]=1$-butyl-3-methylimidazolium hexafluorophosphate $[\mathrm{hmim}]\left[\mathrm{PF}_{6}\right]=1$-hexyl-3-methylimidazolium hexafluorophosphate $[\mathrm{hmim}]\left[\mathrm{HSO}_{4}\right]=1$-hexyl-3-methylimidazolium hydrogen sulfate $[\mathrm{hbim}]\left[\mathrm{BF}_{4}\right]=1$-butylimidazolium tetrafluoroborate [emim] $\left[\mathrm{PF}_{6}\right]=1$-ethyl-3-methylimidazolium hexafluorophosphate [bbim $][\mathrm{Br}]=1,3$-dibutylimidazolium bromide [pmim $][\mathrm{Br}]=1$-propyl-3-methylimidazolium bromide $[$ moemim $][$ TFA $]=1-$ methoxyethyl-3-methylimidazolium trifluoroacetate $[\mathrm{TMG}][\mathrm{Lac}]=1,1,3,3$-tetramethylguanidine lactate $\left[\left(\mathrm{CH}_{2}\right)_{4} \mathrm{SO}_{3} \mathrm{hmim}\right]\left[\mathrm{HSO}_{4}\right]=1$-(4-sulfonic acid)butyl-3-methylimidazolium hydrogen sulfate [omim $]\left[\mathrm{BF}_{4}\right]=1$-octyl-3-methylimidazolium tetrafluoroborate [hemim $]\left[\mathrm{BF}_{4}\right]=1$-hexyl-3-methylimidazolium tetrafluoroborate $\mathrm{bm}_{2} \mathrm{im}=1$-butyl-2,3-dimethylimidazolium bmpyrr = 1-butyl-1-methylpyrrolidinium pmim $=1$-propyl-3-methylimidazolium

Fig. 2 Anions of ionic liquids and common ionic liquids

and it was reused seven times without any much decrease in yield. A variety of structurally diverse aldehydes were used to increase the scope of this method. The $4 \mathrm{H}$-pyrans were obtained from both electron deficient and electronrich aromatic aldehydes [154] (Scheme 1).
Peng and Song [155] utilized a three-component strategy for the synthesis of $4 \mathrm{H}$-pyrans derivatives under microwave irradiation in the presence of a recyclable and environmentally benign reaction medium i.e. the mixture of catalytically active 1-methyl-3-(2-aminoethyl) 
Scheme 1 Synthesis of $4 H$-pyrans<smiles>CCOC(=O)CC(C)=O</smiles><smiles>N#CCC=O</smiles><smiles>CCOC(=O)C1=C(C)OC(N)=C(C#N)C1c1ccccc1</smiles>

phenyl ring substituents have shown that electron-withdrawing groups favored the reaction while electron-releasing groups not. For higher reaction rates and yields the ionic liquids solvent was found to be superior than ethanol (yields 60-80\%) [154] (Scheme 3).

Various natural products possess $4 \mathrm{H}$-pyran and therefore have attracted the attention of chemists $[163,164]$. The preparation of oxygen containing heterocyclic compounds is slightly more complex, because to affect the final ring-closing step only reduced numbers of suitable oxygen nucleophiles were available. The $4 \mathrm{H}$-pyran derivatives have high reactivity and are used as synthons for the construction of more complex species. Addition of malononitriles, aromatic aldehydes, and $\beta$-dicarbonyl was performed in [bmim] $\left[\mathrm{BF}_{4}\right]$ and 1,1,3,3-tetramethylguanidine catalyst to afford highly substituted $4 \mathrm{H}$-pyrans (Scheme 4) $[165,166]$.

The exo-methylene five- and six-membered lactones were synthesized selectively in high yields by an intramolecular alkoxy carbonylation of alkynols with the aid of $\mathrm{Pd}$ -

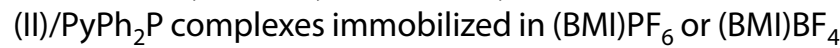
[167]. Catalyst recycling and product isolation was done in the same way as that of carbonylation of aryl halides [168] (Scheme 5).

The unexpected product methyl 6-(4-methoxyphenyl)$2 \mathrm{H}$-pyran-3-carboxylate was obtained in $80 \%$ yield by mixing (Z)-methyl 5-chloro-3-hydroxy-5-(4-methoxyphenyl)2-methylenepent-4-enoate $(1.0 \mathrm{mmol})$ with $\mathrm{NaNO}_{3}$ $(1.1 \mathrm{mmol})$ at $80{ }^{\circ} \mathrm{C}$ in ionic liquid [hmim] $\mathrm{HSO}_{4}$ for $12 \mathrm{~h}$ (Scheme 6) [169].

Various aldehydes and homoallylic alcohols underwent Prins cyclization at room temperature in $\mathrm{Et}_{4} \mathrm{NF} \cdot 5 \mathrm{HF}$. The fluorinated tetrahydropyrans were obtained with high

Scheme 3 Synthesis of 2-amino-4H-pyrans<smiles>CCOC(=O)CC(C)=O</smiles><smiles>N#CCC#N</smiles><smiles>CCOC(=O)C1=C(C)OC(N)=C(C#N)C1c1ccccc1</smiles> 
Scheme 4 Synthesis of $4 H$-pyrans<smiles>CCOC(=O)CC(C)CCCCCCC#N</smiles>

Scheme 5 Synthesis of 4,5-dimethyl-3-methylenetetrahydro-2H-pyran-2-one

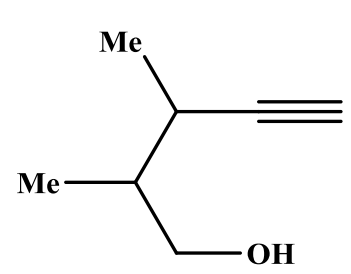

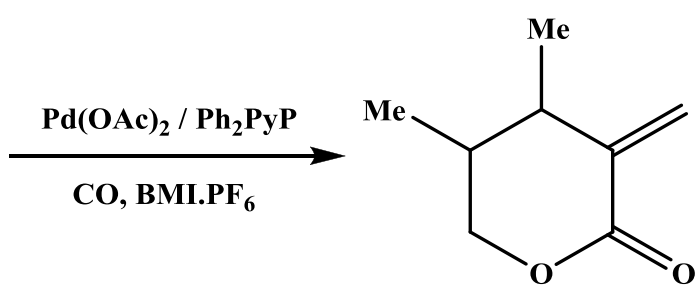

Scheme 6 Synthesis of methyl 6-(4-methoxyphenyl)-2H-pyran-3-carboxylate

Scheme 7 Synthesis of tetrahydropyrans

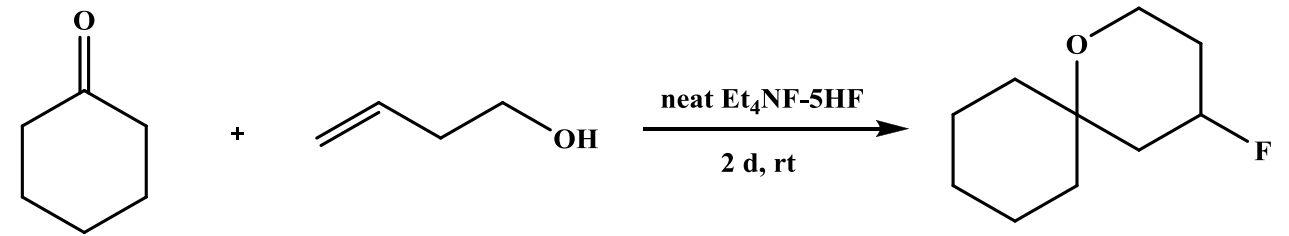

stereoselectivity (cis products were formed exclusively) in excellent yields by Prins cyclization of an alicyclic aldehyde, an aliphatic aldehyde and an aromatic aldehyde with a homoallylic alcohol $[170,171]$. The expected products were observed in a same way, irrespective of the substituents at para position of benzaldehyde. The 2,4,6-trisubstituted tetrahydropyrans were obtained in quantitative yields reacting 1-substituted homoallylic alcohols with aldehydes. No or quite low reactivity was reported for ketones. Sabitha and co-workers [172] reported Prins cyclization of many ketones with homoallylic alcohols in the presence of trimethylsilyl iodide (TMSI). The protons of $\mathrm{Et}_{4} \mathrm{NF} \cdot 5 \mathrm{HF}$ have low capacity to activate the carbonyl groups as indicated by these results. However, the spiro product was only obtained by reacting cyclic ketone (Scheme 7) [173].

The photo-oxygenation of furans was carried out in ionic liquid reaction media using singlet oxygen [174]. The [bmim] $\mathrm{BF}_{4}$ and [emim] $\mathrm{Br}$ (1-ethyl-3-methylimidazolium bromide) ionic liquids were utilized and the obtained results were compared with those of acetonitrile and water. Acetonitrile ( $10 \% \mathrm{v} / \mathrm{v}$, to dissolve the solid salt) and water $(50 \% \mathrm{v} / \mathrm{v}$, to ensure solubility of substrates) were used as co-solvent with [emim] Br because at room temperature [emim] Br is not a liquid. Methylene blue and rose bengal were employed as sensitizers and a halogen lamp was utilized for irradiation. The influence on the fate of the endo-peroxide was investigated using a number of substituents (Scheme 8).

This procedure was utilized for concise synthesis of $( \pm)$-centrolobine to ensure the feasibility of intramolecular hydroalkoxylation in Bronsted acidic ionic liquids (Scheme 9). The stem of Brosinium potabile in the Amazon forest and heartwood of Centrolobium robustum contain an antiprotozoal natural product (-)-centrolobine [175-177]. For the synthesis of tetrahydropyran skeleton there is no example that involved an intramolecular hydroalkoxylation as a key step. The tetrahydropyran skeleton was produced by an atom economical method from alkenyl alcohol in the presence of Bronsted acidic 


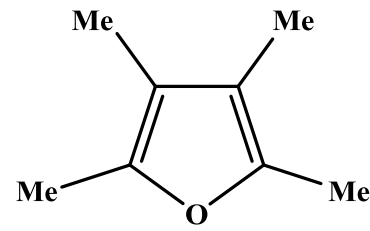

$\downarrow^{h v, \mathrm{O}_{2}}$<smiles>CC1=C2OC2c2oc1c(C)c2C</smiles>

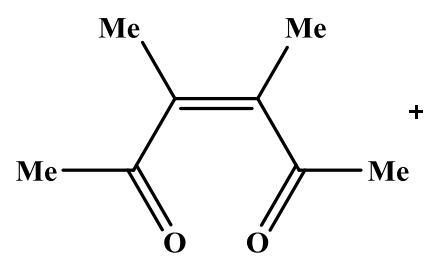

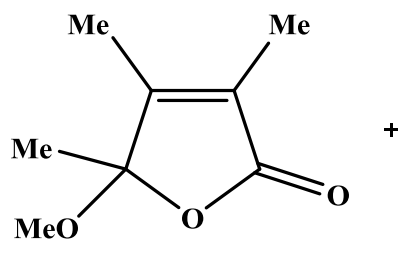
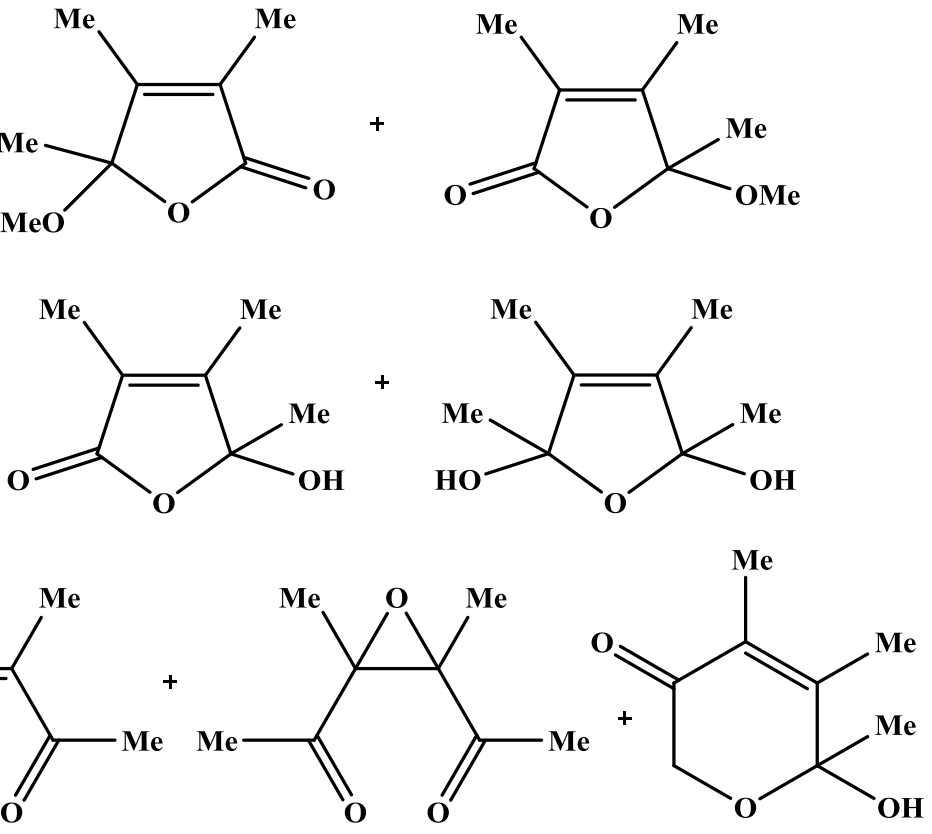

Scheme 8 Synthesis of furans and pyran

ionic liquid via intramolecular hydroalkoxylation. The anisaldehyde by vinyl magnesium bromide addition provided allylic alcohol. The allylic alcohol was used for initiating the synthesis and was subjected to one-pot vinylationClaisen rearrangement conditions [178]. This vinylation and Claisen rearrangement involving one-pot conversion was performed effectively in refluxing $n$-butyl vinyl ether. The $a, \beta$-unsaturated aldehyde was yielded in $83 \%$ yield in two steps from in situ generated allyl vinyl ether. The alkenyl alcohol was produced by the addition of phenethyl magnesium bromide and magnesium in THF (tetrahydrofuran). The alkenyl alcohol acts as a starting substrate for hydroalkoxylation. The triazolium ionic liquid and imidazolium ionic liquid both were effective for preparing cyclized tetrohydropyran at room temperature in $82 \%$ and $77 \%$ yields, respectively. Only cis-disubstituted tetrahydropyran was observed. The catalytic hydrogenation removed the benzyl group in $98 \%$ yield [179-197].

\subsection{Synthesis of six-membered O-polyheterocycles}

Flavanone has antibacterial activities against Escherichia coli, Bacillus subtalis, Staphylococcus aureus and Pseudomonas aeruginosa. The substituted 2-phenylchroman4-one i.e. flavanone were synthesized in high yield using ionic liquid $\mathrm{H}\left[\mathrm{bimBF}_{4}\right]$ at room temperature from substituted $\alpha, \beta$-unsaturated carbonyl compounds $(E)$ chalcones. The ionic liquid $\mathrm{H}\left[\mathrm{bimBF}_{4}\right]$ was recyclable. The filter paper disc diffusion method was performed for in vitro screening of antibacterial activity of synthesized compounds.
Excellent yield of flavanone was obtained at room temperature irradiation in ionic liquid catalyst, $\mathrm{H}\left[\mathrm{bimBF}_{4}\right]$ in short reaction time (Scheme 10). The ionic liquid was recovered and reused many times [198-200]. For a specified time the $\alpha, \beta$-unsaturated carbonyl compounds were grinded in ionic liquid $\mathrm{H}\left[\mathrm{bimBF}_{4}\right]$. The reaction progress was monitored by TLC (thin layer chromatography). The $50 \%$ ethylacetate in petroleum ether was utilized for the extraction of reaction mixture after the completion of reaction. The compound was observed in organic layer, was washed with water, brine and dried over $\mathrm{MgSO}_{4}$. Pure flavanones were isolated after evaporation of organic solvent. Under reduced pressure the ionic liquid was dried and reused with same yield [201].

Various biological activities are possessed by naturally occurring flavones [202-204]. The flavones were synthesized by different protocols such as Allan-Robinson synthesis [205], the use of chalcones [206] and the Wittig reaction $[207,208]$. The Baker-Venkatraman rearrangement was most common procedure for the synthesis of flavones. The 2-phenyl-4H-chromen-4-ones were furnished in high yield in short reaction time from substituted 1-(2-hydroxyphenyl)-3-phenyl-1,3-propane diones under $\mathrm{MW}$ irradiation in the presence of $\left[\mathrm{EtNH} \mathrm{H}_{3}\right] \mathrm{NO}_{3}$ ionic liquid. The benzoyl ester was formed from 2-hydroxyacetophenone. The formed benzoyl ester provided 1,3-diketone in base (pyridine/ $\mathrm{KOH}$ ). The flavones were produced from cyclization of 1,3-ketones under strongly acidic conditions [209]. The flavones were synthesized from various substituted diketones under microwave irradiation in 
<smiles>C=CC(O)c1ccc(OC)cc1</smiles><smiles>C#COC(C=C)c1ccc(OC)cc1</smiles>

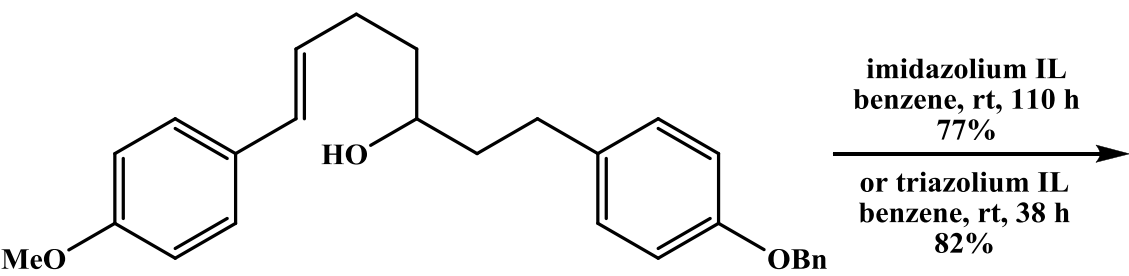<smiles>COc1ccc(CC[C@H]2C[C@@H](c3ccc(OC)cc3)C[C@H](CCc3ccc(O)cc3)O2)cc1</smiles>

Scheme 9 Synthesis of tetrahydropyran

Scheme 10 Synthesis of 2-phenylchroman-4-one<smiles>O=C(/C=C/c1ccccc1)c1cccc2c1OC(c1ccccc1)CC2=O</smiles>

the presence of an ionic liquid catalyst, ethyl ammonium nitrate $\left(\left[\mathrm{EtNH}_{3}\right]\left[\mathrm{NO}_{3}\right]\right)$ without the formation of any side product except water (Scheme 11). The ionic liquid was utilized in a molar ratio of 1:2 (reactant/IL), and it was recovered and reused two times with only little decrease in activity. The simplicity in procedure and work up, mild reaction conditions and good yields were benefits of this reaction. The flavone derivatives were formed in $82 \%$ yield when the reaction was carried out under acidic conditions $(\mathrm{HCl})$ in a molecular solvent (acetic acid) by reflux

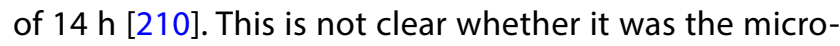
wave irradiation or the ionic liquid that increased the efficiency of reaction. The ionic liquid was good alternative to a molecular solvent $[211,212]$. The ionic liquid $\left[\mathrm{EtNH}_{3}\right]$ 
$\mathrm{NO}_{3}$ was synthesized as described in literature [198-200]. The 1,3-diketones were irradiated in a domestic microwave oven in ionic liquid [EtNH $\mathrm{N}_{3} \mathrm{NO}_{3}$ for a specified time period. Pure flavones were observed in $80-90 \%$ yield after completion of the reaction and extraction with organic solvent followed by aqueous work-up. Due to the water solubility of ionic liquid, it goes into the aqueous layer. The ionic liquid (about 90\%) was left behind after distilling the aqueous layer under vacuum at $80^{\circ} \mathrm{C}$ to remove water $[154,156,213-215]$.

The important derivatives of benzopyrans i.e. coumarins were prepared by Wittig reactions (Scheme 12) in the presence of acidic or basic catalysts [216].

Tetrahydrobenzo[b]pyran derivatives can be synthesized by a multi-component reaction of an aromatic aldehyde, dimedone and malonitrile in the presence of both acidic as well as basic catalysts. Recently, Peng and Song [153] carried out this multi-component reaction (MCR) by replacing dimedone by $\beta$-ketoester and synthesized new derivatives of pyrans by employing a mixture of water and ionic liquid, while for the same purpose Babu et al. [217] used a heterogeneous strong basic Mg/La mixed oxide catalyst in methanol (Scheme 13) [218].

The coumarins were synthesized using an acid catalyzed Pechmann reaction by condensing phenols with $\beta$-ketoesters. Many reagents, such as sulfuric acid [219], phosphorus pentoxide [220], aluminium chloride [221], and trifluoroacetic acid [222], have been employed in this reaction. Environmentally benign and gentle reagents (oxalic acid, $\mathrm{SnCl}_{2}$, silica triflate, alum $\left(\mathrm{KAl}\left(\mathrm{SO}_{4}\right)_{2} \cdot \mathrm{H}_{2} \mathrm{O}\right.$ ) and iodine [223-228]) were preferably used in this reaction. Pechmann condensation for the coumarin synthesis was promoted in both neutral [229] and acidic [230-232] ionic liquids. Singh and co-workers [233] combined microwave irradiation and an ionic liquid for this reaction. The Bronsted acidic [bmim] $\left[\mathrm{HSO}_{4}\right]$ ionic liquid was used as a catalyst under conventional reflux conditions and it was observed that less yields of coumarins in much more times were reported in comparison to microwave conditions (Scheme 14).

The 5-oxo-5,6,7,8-tetrahydro-4Hbenzo[b]pyran was synthesized with dimedone (1,3-dicarbonyl source) in [hmim] $\left[\mathrm{BF}_{4}\right]$ (1-hexyl-3-methylimidazolium tetrafluoroborate), [bmim] $\left[\mathrm{BF}_{4}\right]$, [omim] $\left[\mathrm{PF}_{6}\right]$ (1-octyl-3-methylimidazolium hexafluorophosphate), [omim] $\left[\mathrm{BF}_{4}\right]$ (1-octyl-3-methylimidazolium tetrafluoroborate) and [DMIM] $\left.\mathrm{PF}_{6}\right]$ (3-methylimidazolium hexafluorophosphate). No additional catalyst was needed and the reactions completed in 2-6 h in yields ranging from 52 to $98 \%[234,235]$. The group of Fang et al. [236] developed a modified condensation of malononitrile

Scheme 11 Synthesis of 2-phenyl-4H-chromen-4-ones<smiles>O=C(CC(=O)c1ccccc1O)c1ccccc1</smiles>

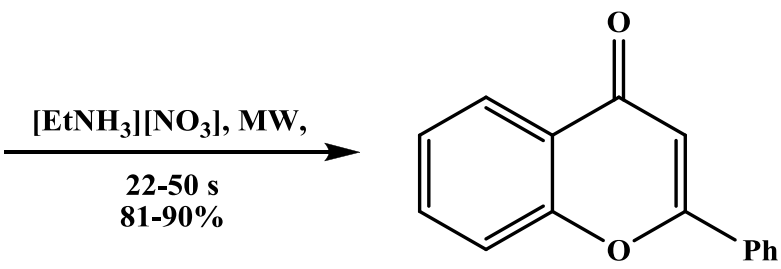<smiles>O=Cc1ccccc1O</smiles><smiles>COC(=O)CCl</smiles><smiles>O=c1ccc2ccccc2o1</smiles>

Scheme 12 Synthesis of coumarins<smiles>CC(=O)[OH+]CC1(C)CC(=O)CC(C)(C)C1</smiles><smiles>N#CCC#N</smiles><smiles>CC1C(C#N)=C(N)OC2=C1C(=O)CC(C)(C)C2</smiles>

Scheme 13 Synthesis of tetrahydrobenzo[b]pyran 
(or ethyl cyanoacetate), aromatic aldehyde, and dimedone (or 1,3-cyclo-hexanedione) for the generation of more highly substituted 5-oxo-5,6,7,8-tetrahydro-4H-benzo[b] pyrans with acidic ionic liquids like [TBPSA] [HSO $\left.{ }_{4}\right]$, [TEBSA] $\left[\mathrm{HSO}_{4}\right],[\mathrm{EDPSA}]\left[\mathrm{HSO}_{4}\right]$ in water (Scheme 15). The products were obtained in good yields (86 to 94\%) [164, 237-240].

Zhou and co-workers [241] reported the microwaveassisted intramolecular Stetter reaction of 3-ethyl-5-(2hydroxyethyl)-4-methylthiazolium bromide using imidazolium-type room temperature ionic liquids (RT ILs) as solvents. The reaction conditions were optimized by intramolecular Stetter reaction of (E)-methyl 4-(2-formylphenoxy) but-2-enoate in the presence of butylmethylimidazolium tetrafluoroborate $[\mathrm{bmim}]^{+}\left[\mathrm{BF}_{4}\right]^{-}$solvent. The salts of many heterocycles, including imidazolium salts, were utilized as catalysts. The ionic liquids played the role of solvent as well as of catalyst, although it is less active than thiazolium salts, and furnished poor yields of the expected product. The yield was improved to $96 \%$ on increasing the quantity of thiazolium salt from 5 to $15 \mathrm{~mol} \%$. A number of aromatic substrates undergo the intramolecular Stetter reaction under microwave irradiation with thiazolium salts and $\mathrm{Et}_{3} \mathrm{~N}$ catalysts in imidazolium-type room temperature ionic liquids as solvents. The reactions were completed in 5-20 min and good to excellent yields of products were observed under these conditions, usually higher than those obtained under conventional heating conditions. The ionic liquid and thiazolium salts catalyst were recyclable and reusable (Scheme 16).

Many 2-alkyl-substituted chromanones were synthesized in basic ionic liquid catalyst. Two consecutive reactions were comprised in one-step by using basic ionic liquid, [bmim] $\mathrm{OH}$. The ortho-acylphenols were condensed with terminal alkynoates in [bmim] $\mathrm{OH}$ as a catalyst, followed by intramolecular cyclization. The remarkable features of this synthetic protocol are green reaction conditions and reusability of catalyst with good yields. The chromanone was prepared by coupling of orthohydroxy acetophenone and ethyl propiolate in the presence of basic ionic liquid [bmim] OH to optimize the reaction conditions (Scheme 17). This reaction occurred in two steps: in the first step hydroxyl group of phenol was protected, in second step 2-alkyl substituted chromanone derivative was synthesized by cyclization. Authors tried to prepare

Scheme 14 Synthesis of coumarins
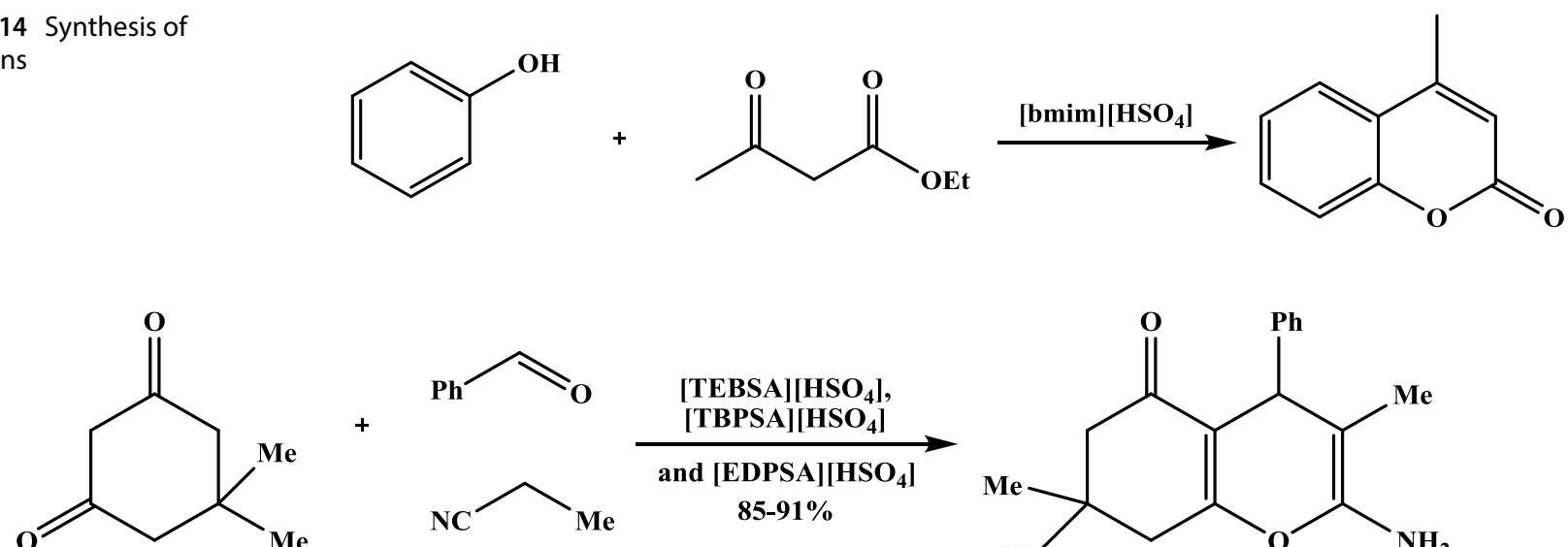<smiles>CC1=C(N)OC2=C(C(=O)CC(C)(C)C2)C1c1ccccc1</smiles>

Scheme 15 Synthesis of 5-oxo-5,6,7,8-tetrahydro-4H-benzo[b]pyran<smiles>CC[n+]1csc(CCO)c1C</smiles>

Scheme 16 Synthesis of methyl 2-(7-chloro-4-oxochroman-3-yl)acetate 


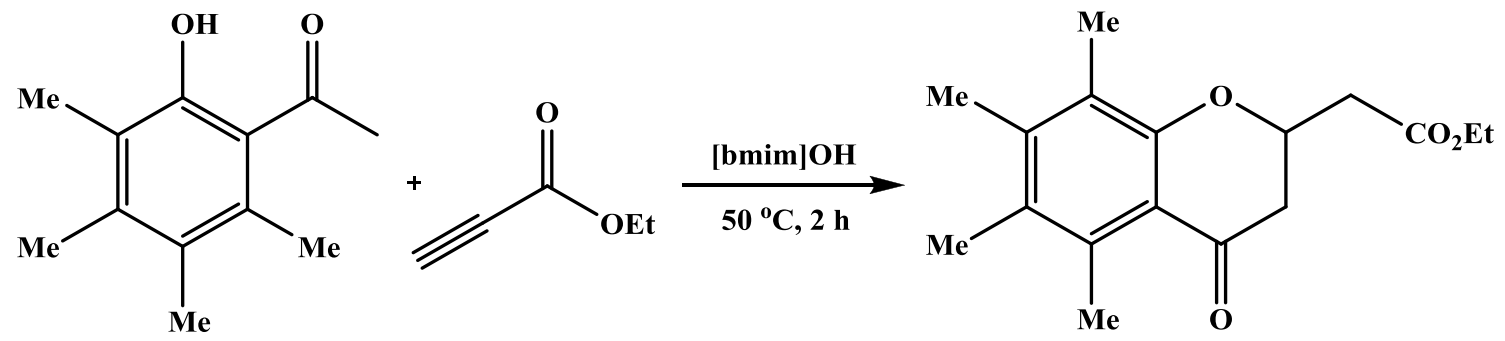

Scheme 17 Synthesis of 2-alkyl-substituted chromanones

Scheme 18 Synthesis of coumarin<smiles>O=Cc1ccccc1O</smiles><smiles>CCOC(=O)CC(C)=O</smiles><smiles>CC(=O)c1cc2ccccc2oc1=O</smiles><smiles>CCOC(=O)c1cc2ccccc2oc1=O</smiles>

Scheme 19 Synthesis of ethyl 2-oxo-2H-chromene-3-carboxylate

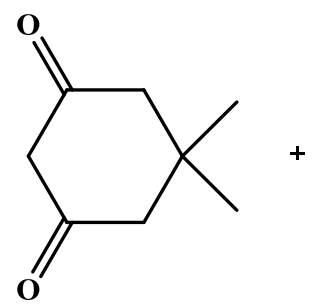<smiles>N#CCC#N</smiles><smiles>CC1(C)CC(=O)C2=C(C1)OC(N)=C(C#N)C2c1ccccc1</smiles>

Scheme 20 Synthesis of $4 \mathrm{H}$-benzo[b]pyran

2-alkyl substituted chromanone derivative in a single step using [bmim] $\mathrm{OH}$ ionic liquid catalyst. This indicated the efficiency of [bmim] OH catalyst [242].

The Knoevenagel condensation of many ketones, aromatic and aliphatic aldehydes with active methylenes was efficiently catalyzed by basic ionic liquid [bmim] $\mathrm{OH}$ (1-butyl-3-methylimidazolium hydroxide) under solventfree conditions at room temperature. The coumarin was furnished in very high yields by one-pot condensation of an aromatic o-hydroxy aldehyde with ethyl acetoacetate or diethyl malonate (Scheme 18) [243, 244].

The Knoevenagel condensation between aldehydes or ketones with active methylene compounds was performed with EDDA (ethylenediammonium diacetate) catalyst in ionic liquid 1-butyl-3-methylimidazonium tetrafluoroborate $[\mathrm{bmim}] \mathrm{BF}_{4}$. Solvent and catalyst are recyclable [245] (Scheme 19).
The described method has the merits of simple operation, environmentally benign, convenient workup, good yields and economic efficiency. The $4 \mathrm{H}$-benzo[b]pyran derivatives were synthesized by a clean, simple and environment friendly three-component reaction in basic ionic liquid $\left[\mathrm{PhCH}_{2} \mathrm{Me}_{2} \mathrm{~N}^{+} \mathrm{CH}_{2} \mathrm{CH}_{2} \mathrm{NMe}_{2}\right] \mathrm{Cl}^{-}$( $\mathrm{N}, \mathrm{N}$-dimethyl aminoethylbenzyldimethylammonium chloride) as an efficient catalyst without the need of solvent (Scheme 20). The excellent yields of desired products in good purity were obtained under solvent-free condition when a number of aromatic aldehydes were condensed with malononitrile and 5,5-dimethylcyclohexane-1,3-dione (dimedone) [244, 246].

The green, efficient and one-pot formation of tetrahydrobenzo[b]pyran derivatives was promoted by basic ionic liquid, [bmim] OH (Scheme 21). The role of reaction medium as well as catalyst was played by ionic liquid. 
<smiles>CC1(C)CC(=O)CC(=O)C1</smiles><smiles>CC1(C)CC(=O)C2=C(C1)OC(N)=C(C#N)C2c1ccccc1</smiles>

Scheme 21 Synthesis of tetrahydrobenzo[b]pyran

The ionic liquid can be used for up to five times without decrease in productivity $[244,247]$.

The condensation of salicylaldehyde or its derivatives with ethyl acetoacetate was promoted by L-proline in neutral ionic liquid [emim] $\mathrm{BF}_{4}$. The ionic liquid containing L-proline was recyclable and can be reused many times without loss in activity. All reactions provided high yields under mild reaction conditions. The L-proline-[emim]BF system contributed to the development of inexpensive and environmentally benign methods in organic syntheses. The efforts began with salicylaldehyde and ethyl acetoacetate in ionic liquid [emim] $\mathrm{BF}_{4}$ at room temperature without L-proline. The catalytic activity of L-proline for these reactions was investigated, and no reaction took place in ionic liquid in $24 \mathrm{~h}$ in the absence of L-proline. When $5 \mathrm{~mol} \%$ L-proline was added, the reaction yield was $85 \%$, and when $40 \mathrm{~mol} \%$ L-proline was added, the reaction yield increased to $95 \%$. However, using $50 \mathrm{~mol} \%$ L-proline resulted in lower yield. The amount of ionic liquid used in the reaction was also optimized, and the results show that the yield increased as the amount of ionic liquid increased from $0.5 \mathrm{ml}$ to $1 \mathrm{ml}$; however, the yield began to decrease as ionic liquid increased to $1.5 \mathrm{ml}$. Therefore, the best result was observed when $40 \mathrm{~mol} \%$ L-proline was used as a promoter in $1 \mathrm{ml}$ ionic liquid. The reaction gave almost no products in $\mathrm{CH}_{3} \mathrm{CN}$, tetrahydrofuran (THF), and $\mathrm{CH}_{2} \mathrm{Cl}_{2}$, and yielded a low level of dimethyl sulfoxide (DMSO) in the presence of L-proline when the reaction time was prolonged to $48 \mathrm{~h}$. In summary, both L-proline and [emim] $\mathrm{BF}_{4}$ had an important effect to the reaction: without one of the two, the reaction would not take place. Since the L-proline and ionic liquid [emim] $\mathrm{BF}_{4}$ are soluble in water, they were extracted with water and the solid material was filtered off to give high purity products. The water solution containing L-proline was distilled under a reduced pressure, and the remaining ionic liquid containing L-proline was recycled and reused at least five times without noticeably decreasing the productivity. Compared with conventional methods, the L-proline-[emim] $\mathrm{BF}_{4}$ system offers a clean, efficient, eco-friendly protocol for the synthesis of coumarins, with a high yield and a simple work-up procedure, and also a recyclable reaction medium [248] (Scheme 22).

In 1995 Cignak and co-workers [249] described the first detailed investigation of the intramolecular Stetter reaction using achiral triazolium salts. A year later, Enders et al. [250] reported the first asymmetric example of the intramolecular Stetter reaction using triazolium (Scheme 23). The 4-chromanone products are obtained in good yield and moderate enantioselectivity.

Various chromones were obtained in very good yields by this selective and efficient ligand-free cyclocarbonylation reaction of $o$-iodophenols and terminal acetylenes with the help of palladium catalyst under atmospheric $\mathrm{CO}$ pressure. The efficiency of the cyclocarbonylation reaction was increased when phosphonium salt ionic liquid was utilized as a reaction medium [251] (Scheme 24).

The activity of metal triflates was dramatically improved using hydrophobic ionic liquids. The Friedel-Crafts alkenylations of aromatic compounds with various alkyl- and aryl-substituted alkynes were conducted in the presence of metal triflates [252] (Scheme 25).

Flavones were produced from substituted 1-(2-hydroxy phenyl)-3-phenyl-1,3-propane diones with the help of $n$-butyl-3-methyl-imidazolium tetrafluoroborate ionic liquid. The reaction of 1,3-diketones was studied in 1-n-butyl3-methyl imidazolium tetrafluoroborate $[\mathrm{bmim}] \mathrm{BF}_{4}$ at $100{ }^{\circ} \mathrm{C}$ in model reaction. The aqueous work-up after the completion of reaction gave pure flavones in high yields. Many substituted diketones were synthesized by this well known protocol to see its synthetic utility [62]. The
Scheme 22 Synthesis of coumarins<smiles>CC(=O)c1ccccc1O</smiles><smiles>CCOC(=O)CC(C)=O</smiles><smiles>CC(=O)c1c(C)c2ccccc2oc1=O</smiles> 
<smiles>CCOC(=O)/C=C/COc1ccccc1C=O</smiles>

Scheme 23 Synthesis 4-chromanone

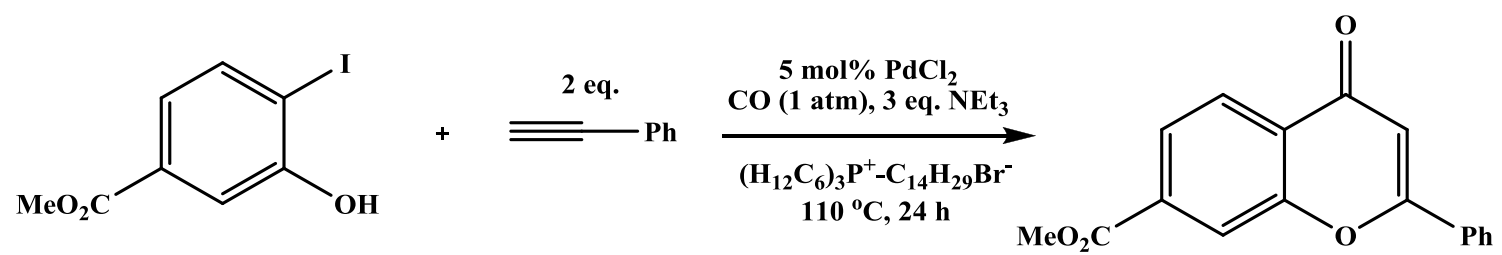

Scheme 24 Synthesis of chromones

Scheme 25 Synthesis of 4-methyl-2H-chromen-2-one<smiles>CC#CC(=O)Oc1ccccc1</smiles><smiles>Cc1cc(=O)oc2ccccc12</smiles>

Scheme 26 Synthesis of 2-phenyl-4H-chromen-4-one<smiles>O=C(CC(=O)c1ccccc1O)c1ccccc1</smiles><smiles>O=c1cc(-c2ccccc2)oc2ccccc12</smiles>

flavones possessing $\mathrm{Cl}, \mathrm{NO}_{2}$, hydroxy and methoxy groups in the aromatic rings were obtained cleanly in high yields without any undesirable side reaction. This method has advantages such as fast reaction rate, simple and easy procedure, excellent yields and mild reaction conditions. The ionic liquid was recovered and reused many times with no loss in productivity [253-257] (Scheme 26).

The $4 H$-benzo[b]pyrans are biologically important. The excellent yields (77-95\%) of $4 \mathrm{H}$-benzo[b]pyrans were obtained after stirring at ethanol reflux for 30-50 min. The [bmim] $[\mathrm{OH}]$ ionic liquid was employed as a catalyst in this synthetic protocol $[144,164]$ (Scheme 27).
The reaction was performed with another active methylene compound, 4-hydroxycoumarin, in place of 1,3-cyclohexanedione or dimedone. The benzaldehyde, 4-hydroxycoumarin and urea were condensed using TMSCl (trimethylsilyl chloride) catalyst in [bmim] $\mathrm{BF}_{4}$. However, according to spectral data and melting point surprisingly the isolated product was found to be 3,3'-benzylidenebis-(4-hydroxycoumarin), and unreacted urea was observed in reaction mixture. Simple heating of aldehyde and 4-hydroxycoumarin at $60-70^{\circ} \mathrm{C}$ in ionic liquid in the absence of catalyst provided biscoumarins. Under similar conditions, a range of aromatic, 
heteroaromatic and aliphatic aldehydes were condensed with 4-hydroxycoumarin. Excellent yields of biscoumarins were obtained from all aldehydes (Scheme 28) [258].

\subsection{Synthesis of six-membered two oxygen containing heterocycles}

The olefins were condensed with aldehydes via acidcatalyzed Prins reaction for carbon-carbon bond formation in organic synthesis [259]. The main products of the classical Prins reaction are 1,3-dioxanes, 1,3-diols, unsaturated alcohols and the products of acid-catalyzed polymerization of olefins $[260,261]$. Many bioactive natural products were obtained from 1,3-diol building blocks $[262,263]$. The olefins were added to paraformaldehyde in acid catalysts for the synthesis of 1,3-diols. This transformation was promoted in Bronsted acids or Lewis acids in both stoichiometric and catalytic amounts [264-271]. Yadav et al. [272] employed catalytic amount of indium tribromide in [bmim] $\left[\mathrm{PF}_{6}\right]$ for the preparation of 1,3-dioxanes. The 1,3-dioxanes were obtained in excellent yields when a number of styrenes were reacted smoothly with paraformaldehyde. The reactions occurred efficiently in all cases with high selectivity at $25^{\circ} \mathrm{C}$. The best results were reported when the reactions were conducted for 3.5-6.5 $\mathrm{h}$ at room temperature in $10 \%$ indium tribromide in ionic liquids (Scheme 29). The ionic liquid was used in a molar ratio of 1:5 (reactant/IL), and it was recovered and reused three times without any much loss in yield. The improved yields, enhanced reaction rates and high selectivity were the major benefits of using ionic liquids in comparison to conventional solvents. The 4,5-diphenyl-1,3-dioxane was obtained in $90 \%$ yield with trans selectivity when transstilbenes were reacted with paraformaldehyde for $5.5 \mathrm{~h}$ in $10 \mathrm{~mol} \%$ indium tribromide in $[\mathrm{bmim}]\left[\mathrm{PF}_{6}\right]$ whereas the product was observed in $70 \%$ yield as cis and trans isomers in a molar ratio of $2: 8$ by same reaction for $8.0 \mathrm{~h}$ in dichloromethane [154, 273, 274].

Although the acetal product formed quickly, it was presumed that acetal formation would be reversible, and with this in mind the one-pot cascade reaction was examined. However, no desired Stetter product was observed. All attempts to overcome the acetal formation failed to provide the desired product [275] (Scheme 30).<smiles>CC(C)C(c1ccc2nc(C3=C(N)OC4=C(C(=O)CC(C)(C)C4)C3c3ccccc3)sc2c1)C(C)(C)C</smiles>

Scheme 27 Synthesis of $4 \mathrm{H}-$ benzo[b]pyrans<smiles>O=Cc1c(O)c2ccccc2oc1=O</smiles>

Scheme 28 Synthesis of biscoumarins

Scheme 29 Synthesis of 4-methyl-4,5-diphenyl-1,3-dioxane

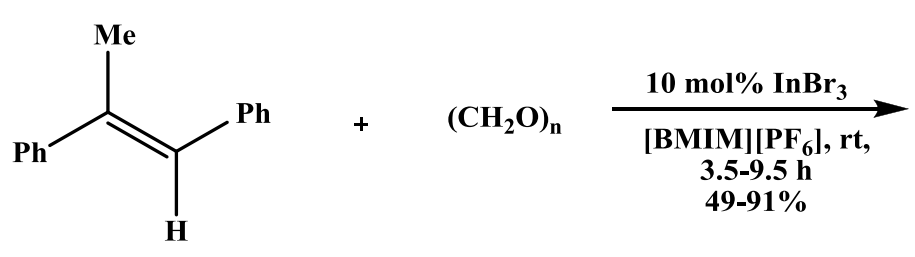<smiles>CC1(c2ccccc2)OCOCC1c1ccccc1</smiles>

SN Applied Sciences 


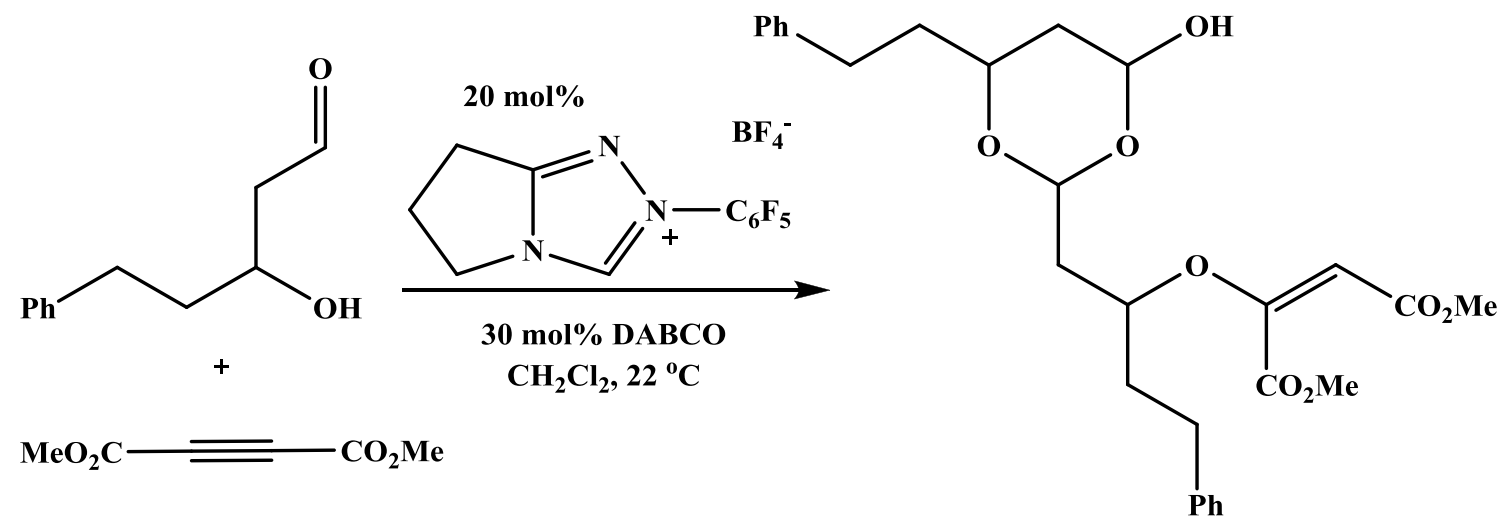

Scheme 30 Synthesis of dimethyl 2-(1-(4-hydroxy-6-phenethyl-1,3-dioxan-2-yl)-4-phenylbutan-2-yloxy)maleate

\section{Compliance with ethical standards}

Conflict of interest The authors declare that they have no conflict of interest.

\section{References}

1. Farghaly AM, Soliman R, Khalil MA, Bekhit AA, Din A, Bekhit A (2002) Thioglycolic acid and pyrazole derivatives of $4(3 H)$ quinazolinone: synthesis and antimicrobial evaluation. Boll Chem Farm 141(5):372-378

2. Kaur N (2015) Palladium-catalyzed approach to the synthesis of S-heterocycles. Catal Rev 57(4):478-564

3. Kaur N (2018) Synthesis of six and seven-membered heterocycles under ultrasound irradiation. Synth Commun 48(11):1235-1258

4. Kaur N (2018) Photochemical reactions as key steps in five-membered $\mathrm{N}$-heterocycles synthesis. Synth Commun 48(11):1259-1284

5. Kaur N (2018) Solid-phase synthesis of sulfur containing heterocycles. J Sulfur Chem 39(5):544-577

6. Reddy CR, Radhika L, Kumar TP, Chandrasekhar S (2011) First acid-catalyzed entry to $O$-alkylated hydroximides from benzylic alcohols. Eur J Org Chem 30:5967-5970

7. Reddy $C R$, Ranjan R, Kumaraswamy $P$, Reddy MD, Grée $R$ (2014) 1-Aryl propargylic alcohols as handy synthons for the construction of heterocycles and carbocycles. Curr Org Chem 18:2603-2645

8. Kumar TP, Radhika L, Haribabu K, Kumar VN (2014) Pyrrolidine-oxyimides: new chiral catalysts for enantioselective Michael addition of ketones to nitroolefins in water. Tetrahedron Asymmetry 25:1555-1560

9. Kaur N (2014) Palladium-catalyzed approach to the synthesis of five-membered $O$-heterocycles. Inorg Chem Commun 49:86-119

10. Kaur N, Kishore D (2014) Nitrogen-containing six-membered heterocycles: solid-phase synthesis. Synth Commun 44(9):1173-1211

11. Kaur N, Kishore D (2014) Solid-phase synthetic approach toward the synthesis of oxygen containing heterocycles. Synth Commun 44(8):1019-1042
12. Kaur N (2014) Microwave-assisted synthesis of five membered O-heterocycles. Synth Commun 44(24):3483-3508

13. Kaur N (2014) Microwave-assisted synthesis of five membered O,N-heterocycles. Synth Commun 44(24):3509-3537

14. Kaur N (2014) Microwave-assisted synthesis of five membered O,N,N-heterocycles. Synth Commun 44(22):3229-3247

15. Párkányi C, Schmidt DS (2000) Synthesis of 5-chloro-2-methyl-3-(5-methylthiazol-2-yl)-4(3H)-quinazolinone and related compounds with potential biological activity. J Heterocycl Chem 37:725-729

16. Kaur N (2018) Ruthenium catalysis in six-membered O-heterocycles synthesis. Synth Commun 48:1551-1587

17. Kaur N (2018) Green synthesis of three to five-membered $O$-heterocycles using ionic liquids. Synth Commun 48:1588-1613

18. Kaur N (2018) Ultrasound-assisted green synthesis of five-membered $O$ - and $S$-heterocycles. Synth Commun 48:1715-1738

19. Kaur N (2018) Photochemical mediated reactions in fivemembered $O$-heterocycles synthesis. Synth Commun 48(17):2119-2149

20. Kaur N (2019) Application of silver-promoted reactions in the synthesis of five-membered $O$-heterocycles. Synth Commun 49:743-789

21. Kaur N (2019) Synthesis of seven and higher-membered heterocycles using ruthenium catalysts. Synth Commun 49:617-661

22. Kikuchi H, Tasaka H, Hirai S, Takaya Y, Iwabuchi Y, Ooi H, Hatakeyama S, Kim HS, Wataya Y, Oshima Y (2002) Potent antimalarial febrifugine analogues against the plasmodium malaria parasite. J Med Chem 45(12):2563-2570

23. Uredi D, Reddy MD, Watkins EB (2018) A unified strategy for the synthesis of $\beta$-carbolines, $\gamma$-carbolines, and other fused. Azaheteroaromatics under mild, metal-free conditions. Org Lett 20:6336-6339

24. Reddy MD, Fronczek FR, Watkins EB (2016) Rh-catalyzed, regioselective, $\mathrm{C}-\mathrm{H}$ bond activation: access to quinoline branched amines and dimers. Org Lett 18:5620-5623

25. Nagesh N, Raju G, Srinivas R, Ramesh P, Reddy MD, Reddy CR (2015) A dihydroindolizino indole derivative selectively stabilizes G-quadruplex DNA and downregulates. c-MYC expression in human cancer cells. Biochim Biophys Acta 1850:129-140

26. Kaur N (2015) Benign approaches for the microwave-assisted synthesis of five-membered 1,2-N,N-heterocycles. J Heterocycl Chem 52:953-973 
27. Kaur N (2017) Methods for metal and non-metal catalyzed synthesis of six-membered oxygen containing poly-heterocycles. Curr Org Synth 14(4):531-556

28. Kaur N (2017) Photochemical reactions: synthesis of six-membered $N$-heterocycles. Curr Org Synth 14(7):972-998

29. Kaur N (2017) lonic liquids: promising but challenging solvents for the synthesis of $\mathrm{N}$-heterocycles. Mini Rev Org Chem 14(1):3-23

30. Kaur N (2016) Metal catalysts for the formation of six-membered $\mathrm{N}$-polyheterocycles. Synth React Inorg Met Org NanoMet Chem 46(7):983-1020

31. Kaur N (2017) Applications of gold catalysts for the synthesis of five-membered O-heterocycles. Inorg Nano-Met Chem 47(2):163-187

32. Kaur N (2018) Copper catalysts in the synthesis of five-membered $N$-polyheterocycles. Curr Org Synth 15:940-971

33. Kaur N (2018) Recent developments in the synthesis of nitrogen containing five-membered polyheterocycles using rhodium catalysts. Synth Commun 48:2457-2474

34. Kaur N (2015) Metal catalysts: applications in higher membered $N$-heterocycles synthesis. J Iran Chem Soc 12:9-45

35. Kaur N (2015) Insight into microwave-assisted synthesis of benzo derivatives of five membered $\mathrm{N}, \mathrm{N}$-heterocycles. Synth Commun 45(11):1269-1300

36. Kaur N (2015) Synthesis of fused five-membered $N, N$-heterocycles using microwave irradiation. Synth Commun 45(12):1379-1410

37. Kaur N (2014) Microwave-assisted synthesis of seven membered S-heterocycles. Synth Commun 44(22):3201-3228

38. Kaur N (2015) Six membered $N$-heterocycles: microwaveassisted synthesis. Synth Commun 45(1):1-34

39. Kaur N (2015) Polycyclic six membered $N$-heterocycles: microwave-assisted synthesis. Synth Commun 45(1):35-69

40. Hazarkhani $H$, Karimi $B$ (2003) A facile synthesis of new 3-(2-benzimidazoyl)-2-alkyl-4-(3H)-quinazolinones under microwave irradiation. Tetrahedron 59(26):4757-4760

41. Kaur N (2018) Mercury-catalyzed synthesis of heterocycles. Synth Commun 48:2715-2749

42. Kaur N (2018) Photochemical irradiation: seven and higher membered O-heterocycles. Synth Commun 48:2935-2964

43. Kaur N (2018) Synthesis of seven and higher membered nitrogen containing heterocycles using photochemical irradiation. Synth Commun 48:2815-2849

44. Kaur N (2018) Ruthenium catalyzed synthesis of five-membered O-heterocycles. Inorg Chem Commun 99:82-107

45. Maarouf AR, El-Bendary ER, Goda FE (2004) Synthesis and evaluation of some novel quinazolinone derivatives as diuretic agents. Arch Pharm Med Chem 337(10):527-532

46. Kaur N (2019) Applications of palladium dibenzylideneacetone as catalyst in the synthesis of five-membered $\mathrm{N}$-heterocycles. Synth Commun 49:1205-1230

47. Kaur N (2019) Copper catalyzed synthesis of seven and higher-membered heterocycles. Synth Commun 49:879-916

48. Kaur N (2019) Ionic liquid assisted synthesis of S-heterocycles. Phosphorus Sulfur Silicon Relat Elem 194:165-185

49. Kaur N (2019) Nickel catalysis: six membered heterocycle syntheses. Synth Commun 49:1103-1133

50. Kaur N (2019) Seven-membered $N$-heterocycles: metal and non-metal assisted synthesis. Synth Commun 49:987-1030

51. Kaur N, Bhardwaj P, Devi M, Verma Y, Grewal P (2019) Synthesis of five-membered $O, N$-heterocycles using metal and non-metal. Synth Commun 49:1345-1384

52. Kaur N (2019) Synthetic routes to seven and higher membered S-heterocycles by use of metal and nonmetal catalyzed reactions. Phosphorus Sulfur Silicon Relat Elem 194:186-209
53. Kaur N (2019) Synthesis of six-membered $N$-heterocycles using ruthenium catalysts. Catal Lett 14:1513-1539

54. Kaur N (2015) Microwave-assisted synthesis: fused five membered $N$-heterocycles. Synth Commun 45(7):789-823

55. Kaur N (2015) Six membered heterocycles with three and four $\mathrm{N}$-heteroatoms: microwave-assisted synthesis. Synth Commun 45(2):151-172

56. Kaur N (2015) Application of microwave-assisted synthesis in the synthesis of fused six-membered heterocycles with $\mathrm{N}$-heteroatom. Synth Commun 45(2):173-201

57. Kaur N (2015) Microwave-assisted synthesis of fused polycyclic six membered $N$-heterocycles. Synth Commun 45(3):273-299

58. Kaur N (2015) Review of microwave-assisted synthesis of benzo fused six-membered $\mathrm{N}, \mathrm{N}$-heterocycles. Synth Commun 45(3):300-330

59. Kaur N, Kishore D (2014) Synthetic strategies applicable in the synthesis of privileged scaffold: 1,4-benzodiazepine. Synth Commun 44(10):1375-1413

60. Orru RVA, de Greef M (2003) Recent advances in solution phase multicomponent methodology for the synthesis of heterocyclic compounds. Synthesis 10:1471-1499

61. Wassercheid P, Keim W (2000) lonic liquids — new'solutions' for transition metal catalysis. Angew Chem Int Ed 39:3772-3789

62. Sheldon R (2001) Catalytic reactions in ionic liquids. Chem Commun 23:2399-2407

63. Zhao D, Wu M, Kou Y, Min K (2002) lonic liquids: applications in catalysis. Catal Today 74(1-2):157-189

64. Kaur N (2018) Perspectives of ionic liquids applications for the synthesis of five and six-membered $\mathrm{O}, \mathrm{N}$-heterocycles. Synth Commun 48(5):473-495

65. Wang YY, Li W, Dai LY (2008) Bronsted acidic ionic liquids as efficient reaction medium for cyclodehydration of diethylene glycol. Chin J Chem 26(8):1390-1394

66. Kaur N (2015) Environmentally benign synthesis of five membered $1,3-N, N$-heterocycles by microwave irradiation. Synth Commun 45(8):909-943

67. Kaur N (2015) Advances in microwave-assisted synthesis for five membered $\mathrm{N}$-heterocycles synthesis. Synth Commun 45(4):432-457

68. Kaur N (2014) Microwave-assisted synthesis of five membered S-heterocycles. J Iran Chem Soc 11:523-564

69. Kaur N (2015) Review on the synthesis of six membered $N$, $\mathrm{N}$-heterocycles by microwave irradiation. Synth Commun 45(10):1145-1182

70. Kaur N (2015) Greener and expeditious synthesis of fused six-membered $\mathrm{N}, \mathrm{N}$-heterocycles using microwave irradiation. Synth Commun 45(13):1493-1519

71. Kaur N (2015) Applications of microwaves in the synthesis of polycyclic six membered $\mathrm{N}, \mathrm{N}$-heterocycles. Synth Commun 45(14):1599-1631

72. Kaur N (2015) Synthesis of five-membered $N, N, N$-and $N, N, N$, $\mathrm{N}$-heterocyclic compounds: applications of microwaves. Synth Commun 45(15):1711-1742

73. Bao Q, Qiao K, Tomida D, Yokoyama C (2008) Preparation of 5 -hydroymethylfurfural by dehydration of fructose in the presence of acidic ionic liquid. Catal Commun 9(6):1383-1388

74. Shen J, Wang H, Liu H, Sun Y, Liu Z (2008) Bronsted acidic ionic liquids as dual catalyst and solvent for environmentally friendly synthesis of chalcone. J Mol Catal A Chem 280:24-28

75. Reddy MD, Kobori H, Mori T, Wu J, Kawagishi H, Watkins EB (2017) Gram-scale, stereoselective synthesis and biological evaluation of (+)-armillariol C. J Nat Prod 80:2561-2565

76. Reddy CR, Valleti RR, Reddy MD (2013) A thioannulation approach to substituted thiophenes from Morita Baylis Hillman-acetates of acetylenic aldehydes. J Org Chem 78:6495-6502 
77. Reddy CR, Dilipkumar U, Reddy MD (2014) Novel [4 + 2]-benzannulation to access substituted benzenes, polycyclic aromatic and benzene-fused heteroaromatic compounds. Org Lett 16:3792-3795

78. Reddy CR, Sujatha P, Reddy MD (2015) Aza-annulation of enynyl azides: a new approach to substituted pyridines. Org Lett 17:896-899

79. Wang W, Shao L, Cheng W, Yang J, He M (2008) Bronsted acidic ionic liquids as novel catalysts for Prins reaction. Catal Commun 9(3):337-341

80. Venkateshwarlu R, Chinnababu B, Ramulu U, Reddy KP, Reddy MD, Sowjanya P, Rao PV, Aravind S (2017) Synthesis and biological evaluation of (-)-kunstleramide and its derivatives. Med Chem Commun 8:394-404

81. Reddy CR, Reddy MD, Srikanth B, Prasad KR (2011) Morita-Bailys-Hillman acetates of acetylenic aldehydes: versatile synthons for substituted pyrroles via a metal-free tandem reaction. Org Biomol Chem 9:6027-6033

82. Reddy CR, Reddy MD, Srikanth B (2012) Phosphine-mediated cascade reaction of azides with $\mathrm{MBH}$-acetates of acetylenic aldehydes to substituted pyrroles: a facile access to $\mathrm{N}$-fused pyrrolo-heterocycles. Org Biomol Chem 10:4280-4288

83. Reddy CR, Krishna G, Reddy MD (2014) Synthesis of substituted 3-furoates from $\mathrm{MBH}$-acetates of acetylenic aldehydes via tandem isomerization/deacetylation/cycloisomerization: access to Elliot's alcohol. Org Biomol Chem 12:1664-1670

84. Kaur N (2015) Role of microwaves in the synthesis of fused five membered heterocycles with three $\mathrm{N}$-heteroatoms. Synth Commun 45(4):403-431

85. Kaur N (2015) Recent impact of microwave-assisted synthesis on benzo derivatives of five membered $\mathrm{N}$-heterocycles. Synth Commun 45(5):539-568

86. Kaur N, Kishore D (2014) Microwave-assisted synthesis of seven and higher membered $\mathrm{N}$-heterocycles. Synth Commun 44(18):2577-2614

87. Kaur N, Kishore D (2014) Microwave-assisted synthesis of sixmembered S-heterocycles. Synth Commun 44(18):2615-2644

88. Kaur N, Kishore D (2014) Microwave-assisted synthesis of seven and higher membered $O$-heterocycles. Synth Commun 44(19):2739-2755

89. Luo S, Mi X, Zhang L, Liu S, Xua H, Cheng JP (2007) Functionalized ionic liquids catalyzed direct aldol reactions. Tetrahedron 63(9):1923-1930

90. Carvalho PJ, Alvarez VH, Marrucho IM, Aznar M, Coutinho JAP (2009) High pressure phase behavior of carbon dioxide in 1-butyl-3-methylimidazolium bis (trifluoromethylsulfonyl) imide and 1-butyl-3-methylimidazolium dicyanamide ionic liquids. J Supercrit Fluids 50(2):105-111

91. Le Z-G, Chen Z-C, Hu Y, Zheng Q-G (2004) Organic reactions in ionic liquids: a simple and highly regioselective $N$-substitution of pyrrole. Synlett 12:1951-1954

92. Nara SJ, Naik PU, Harjani JR, Salunkhe MM (2006) Potential of ionic liquids in greener methodologies involving biocatalysis and other synthetically important transformations. Indian J Chem 45B:2257-2268

93. Kaur N (2015) Palladium catalysts: synthesis of five-membered $\mathrm{N}$-heterocycles fused with other heterocycles. Catal Rev 57(1):1-78

94. Kaur N, Kishore D (2014) Microwave-assisted synthesis of six membered 0,0 -heterocycles. Synth Commun 44(21):3082-3111

95. Kaur N, Kishore D (2014) Microwave-assisted synthesis of six membered O-heterocycles. Synth Commun 44(21):3047-3081

96. Nair V, Vellalath S, Poonoyh M, Suresh E, Viji S (2007) N-Heterocyclic carbene catalyzed reaction of enals and diaryl-1,2 diones via homoenolate: synthesis of 4,5,5-trisubstituted y-butyrolactones. Synthesis 20:3195-3200

97. Potewar TM, Siddiqui SA, Lahoti RJ, Srinivasan KV (2007) Efficient and rapid synthesis of 1-substituted-1H-1,2,3,4-tetrazoles in the acidic ionic liquid 1-nbutylimidazolium tetrafluoroborate. Tetrahedron Lett 48:1721-1724

98. Xu JM, Qian C, Liu BK, Wu Q, Lin XF (2007) A fast and highly efficient protocol for Michael addition of $N$-heterocycles to a, $\beta$-unsaturated compound using basic ionic liquid [bmim] $\mathrm{OH}$ as catalyst and green solvent. Tetrahedron 63:986-990

99. Hutka M, Toma S (2009) Hydrogen-transfer reduction of aromatic ketones in basic ionic liquids. Monatsh Chem 140:1189-1194

100. Ye C, Xiao JC, Twamley B, LaLonde AD, Norton MG, Shreeve JM (2007) Basic ionic liquids: facile solvents for carbon-carbon bond formation reactions and ready access to palladium nanoparticles. Eur J Org Chem 30:5095-5100

101. Xiao LF, Yue QF, Xia CG, Xu L (2008) Supported basic ionic liquid: highly effective catalyst for the synthesis of 1, 2-propylene glycol from hydrolysis of propylene carbonate. J Mol Catal A Chem 279(2):230-234

102. Liebert T, Heinze $T$ (2008) Interaction of ionic liquids with polysaccharides Solvents and reaction media for the modification of cellulose. Bio Resour 3:576-601

103. Pinkert A, Marsh KN, Pang SS, Staiger MP (2009) Ionic liquids and their interaction with cellulose. Chem Rev 109:6712-6728

104. Kosan B, Michels C, Meister F (2008) Dissolution and forming of cellulose with ionic liquids. Cellulose 15:59-66

105. Wendler F, Kosan B, Krieg M, Meister F (2009) Possibilities for the physical modification of cellulose shapes using ionic liquids. Macromol Symp 280:112-122

106. Cao Y, Li H, Zhang Y, Zhang J, He J (2010) Structure and properties of novel regenerated cellulose films prepared from cornhusk cellulose in room temperature ionic liquids. J Appl Polym Sci 116:547-554

107. Sescousse R, Gavillon R, Budtova T (2011) Aerocellulose from cellulose-ionic liquid solutions: preparation, properties and comparison with cellulose- $\mathrm{NaOH}$ and cellulose-NMMO routes. Carbohydr Polym 83:1766-1774

108. Stark A (2011) lonic liquids in the biorefinery: a critical assessment of their potential. Energy Environ Sci 4:19-32

109. Mora-Pale M, Meli L, Doherty TV, Linhardt RJ, Dordick JS (2011) Room temperature ionic liquids as emerging solvents for the pretreatment of lignocellulosic biomass. Biotechnol Bioeng 108:1229-1245

110. Sun N, Rodriguez H, Rahman M, Rogers RD (2011) Where are ionic liquid strategies most suited in the pursuit of chemicals and energy from lignocellulosic biomass? Chem Commun 47:1405-1421

111. Reddy MD, Uredi D, Watkins EB (2018) A general method for the metal-free, regioselective, remote $\mathrm{C}-\mathrm{H}$ halogenation of 8-substituted quinolines. Chem Sci 9:1782-1788

112. Yue C, Fang D, Liu L, Yi T-F (2011) Synthesis and application of task-specific ionic liquids used as catalysts and/or solvents in organic unit reactions. J Mol Liq 163:99-121

113. Sudina PR, Reddy MD, Seema A (2018) Stereocontrolled total synthesis of nonenolide. J Nat Prod 81:1399-1404

114. Wender PA, Verma VA, Paxton TJ, Pillow TH (2008) Functionoriented synthesis, step economy, and drug design. Acc Chem Res 41:40-49

115. Reddy CR, Dilipkumar U, Reddy MD, Rao NN (2013) Total synthesis and revision of the absolute configuration of seimatopolide B. Org Biomol Chem 11:3355-3364 
116. Candeias NR, Branco LC, Gois PMP, Afonso CAM, Trindade AF (2009) More sustainable approaches for the synthesis of $N$-based heterocycles. Chem Rev 109:2703-2802

117. Smiglak M, Metlen A, Rogers RD (2007) The second evolution of ionic liquids: from solvents and separations to advanced materials-energetic examples from the ionic liquid cookbook. Acc Chem Res 40(11):1182-1192

118. Zorn DD, Boatz JA, Gordon MS (2006) Electronic structure studies of tetrazolium-based ionic liquids. J Phys Chem B 110(23):11110-11119

119. Joo Y-H, Gao H, Zhang Y, Shreeve JM (2010) Inorganic or organic azide-containing hypergolic ionic liquids. Inorg Chem 49(7):3282-3288

120. Schneider S, Hawkins T, Rosander M, Vaghjiani G, Chambreau S, Drake G (2008) lonic liquids as hypergolic fuels. Energy Fuels 22(4):2871-2872

121. Shamshina JL, Smiglak M, Drab DM, Parker TG, Dykes HWH Jr, Di Salvo R, Reich AJ, Rogers RD (2010) Catalytic ignition of ionic liquids for propellant applications. Chem Commun 46:8965-8967

122. Singh RP, Verma RD, Meshri DT, Shreeve JM (2006) Energetic nitrogen-rich salts and ionic liquids. Angew Chem Int Ed 45(22):3584-3601

123. Lin JH, Zhang CP, Zhu ZQ, Chen QY, Xiao JC (2009) A novel pyrrolidinium ionic liquid with 1,1,2,2-tetrafluoro-2-(1,1,2,2-tetrafluoroethoxy)ethanesulfonate anion as a recyclable reaction medium and efficient catalyst for Friedel-Crafts alkylations of indoles with nitroalkenes. J Fluor Chem 130(4):394-398

124. Liu S, Xie C, Yu S, Liu F (2008) Dimerization of rosin using Bronsted-Lewis acidic ionic liquid as catalyst. Catal Commun 9(10):2030-2034

125. Chaskar AC, Bhandari SR, Patil AB, Sharma OP, Mayeker S (2009) Solvent-free oxidation of alcohols with potassium persulphate in the presence of Bronsted acidic ionic liquids. Synth Commun 39:366-370

126. Chaturvedi D (2011) Recent developments on task specific ionic liquids. Curr Org Chem 15:1236-1248

127. Toma S, Meciarova M, Sebesta $R$ (2009) Are ionic liquids suitable media for organocatalytic reactions? Eur J Org Chem 3:321-327

128. Giernoth R (2010) Task-specific ionic liquids. Angew Chem Int Ed 49(16):2834-2839

129. Wu B, Liu WW, Zhang Y, Wang $H$ (2009) Do we understand the recyclability of ionic liquids? Chem Eur J 15:1804-1810

130. Jain N, Kumar A, Chauhan S, Chausan SMS (2005) Chemical and biochemical transformations in ionic liquids. Tetrahedron 61:1015-1060

131. El Seoud OA, Koschella A, Fidale LC, Dorn S, Heinze T (2007) Applications of ionic liquids in carbohydrate chemistry: a window of opportunities. Biomacromol 8:2629-2647

132. Xu JM, Wu Q, Zhang QY, Zhang F, Fu X (2007) Basic ionic liquid as catalyst and reaction medium: a rapid and facile protocol for Aza-Michael addition reactions. Eur J Org Chem 11:1798-1802

133. Chowdhury S, Mohan RS, Scott JL (2007) Reactivity of ionic liquids. Tetrahedron 63:2363-2389

134. Gupta NS, Kad GL, Singh J (2007) Acidic ionic liquid [bmim] $\mathrm{HSO}_{4}$ : an efficient catalyst for acetalization and thioacetalization of carbonyl compounds and their subsequent deprotection. Catal Commun 8:1323-1328

135. Wu HH, Yang F, Cui P, Tang J, He MY (2004) An efficient procedure for protection of carbonyls in Bronsted acidic ionic liquid [hmim] $\mathrm{BF}_{4}$. Tetrahedron Lett 45(25):4963-4965

136. Kim YJ, Varma RS (2005) Microwave-assisted preparation of 1-butyl-3-methylimidazolium tetrachlorogallate and its catalytic use in acetal formation under mild conditions. Tetrahedron Lett 46(43):7447-7449
137. Hajipour AR, Hosseini P, Ruoho AE (2008) Application of $\mathrm{Bu}_{4} \mathrm{~N}^{+}$ $\mathrm{HSO}_{4}{ }^{-}$as an ionic liquid and acid catalyst for thioacetalization of aldehydes and ketones. Phosphorus Sulfur Silicon Relat Elem 183(10):2502-2508

138. Cui S, Lu B, Cai Q, Cai X, Li X, Xiao X, Hou L, Han Y (2006) Highly selective synthesis of diphenylmethane with acidic ionic liquids. Ind Eng Chem Res 45(5):1571-1574

139. Hajipour AR, Rafiee F, Ruoho AE (2007) Facile and selective oxidation of benzylic alcohols to their corresponding carbonyl compounds with sodium nitrate in the presence of Bronsted acidic ionic liquids. Synlett 7:1118-1120

140. Li S, Lin Y, Xie H, Zhang S, Xu J (2006) Bronsted guanidine acidbase ionic liquids: novel reaction media for the palladiumcatalyzed Heck reaction. Org Lett 8(3):391-394

141. Zhang J, Jiang T, Han B, Zhu A (2006) Knoevenagel condensation catalyzed by 1, 1, 3, 3-tetramethylguanidium lactate. Synth Commun 36(22):3305-3317

142. Yavari I, Kowsari E (2007) lonic liquids as novel and recyclable reaction media for $\mathrm{N}$-alkylation of amino-9, 10-anthraquinones by trialkyl phosphites. Tetrahedron Lett 48(21):3753-3756

143. Gong K, Wang HL, Fang D, Liu ZL (2008) Basic ionic liquid as catalyst for the rapid and green synthesis of substituted 2-amino2-chromenes in aqueous media. Catal Commun 9(5):650-653

144. Gong K, Wang HL, Luo J, Liu ZL (2009) One-pot synthesis of polyfunctionalized pyrans catalyzed by 1145 basic ionic liquid in aqueous media. J Heterocycl Chem 46:1145-1150

145. Hajipour AR, Khazdooz L, Ruoho AE (2008) Bronsted acidic ionic liquid as an efficient catalyst for chemoselective synthesis of 1,1 diacetates under solvent free. Catal Commun 9:89-96

146. Qiao K, Yokoyama C (2006) Koch carbonylation of tertiary alcohols in the presence of acidic ionic liquids. Catal Commun 7:450-453

147. Lei Z, Chen B, Koo Y-M, MacFarlane DR (2017) Introduction: ionic liquids. Chem Rev 117:6633-6635

148. Reibstein R (2017) A more ethical chemistry. Curr Opin Green Sustain Chem 8:36-44

149. Vekariya RL (2017) A review of ionic liquids: applications towards catalytic organic transformations. J Mol Liq 227:44-60

150. Ogoshi T, Onodera T, Yamagishi T, Nakamoto Y (2008) Green polymerization of phenol in ionic liquids. Macromolecules 41:8533-8536

151. Gericke M, Fardim P, Heinze T (2012) lonic liquids- Promising but challenging solvents for homogeneous derivatization of cellulose. Molecules 17(6):7458-7502

152. Yi F, Peng Y, Song G (2005) Microwave-assisted liquid-phase synthesis of methyl 6-amino-5-cyano-4-aryl-2-methyl$4 H$-pyran-3-carboxylate using functional ionic liquid as soluble support. Tetrahedron Lett 46:3931-3933

153. Peng Y, Song G (2007) Amino-functionalized ionic liquid as catalytically active solvent for microwave-assisted synthesis of $4 \mathrm{H}$-pyrans. Catal Commun 8:111-114

154. Martins MAP, Frizzo CP, Moreira DN, Zanatta N, Bonacorso HG (2008) lonic liquids in heterocyclic synthesis. Chem Rev 108:2015-2050

155. Peng $Y$, Song G (2004) Microwave-assisted clean synthesis of 6-aryl-2, 4-diamino-1, 3, 5-triazines in [bmim] $\left[\mathrm{PF}_{6}\right]$. Tetrahedron Lett 45:5313-5316

156. Martinez-Palou R (2007) lonic liquid and microwave-assisted organic synthesis: a "Green" and synergic couple. J Mex Chem Soc 51(4):252-264

157. Zamocka J, Misikova E, Durinda J (1991) Preparation, structure elucidation and activity of some (5-hydroxy-) and (5-methoxy4-oxo-4H-pyran-2yl)methyl-2-alkoxycarbanilates. Pharmazie 46:610-613

158. Wang JL, Liu D, Zhang ZJ, Shan S, Han X, Srinivasula SM, Croce CM, Alnemri ES, Huang Z (2000) Structure-based discovery of 
an organic compound that binds $\mathrm{BCl}-2$ protein and induces apoptosis of tumor cells. Proc Natl Acad Sci USA 97:7124-7129

159. O'Callaghan CN, McMurry TBH (1995) Synthetic reactions of methyl XY-carbonyl-4H-1-benzopyran-4yl cyanoethanoate. J Chem Res S 214-218

160. Martin N, Pascual C, Seoane C, Soto JL (1987) The use of some activated nitriles in heterocyclic syntheses. Heterocycles 26:2811-2816

161. Quintela JM, Peinador C, Moreira MJ (1995) A novel synthesis of pyrano[2,3-d]pyrimidine derivatives. Tetrahedron 51:5901-5912

162. Peng $Y$, Song G, Huang F (2005) Tetramethylguanidine-[bmim] $\left[\mathrm{BF}_{4}\right]$. An efficient and recyclable catalytic system for one-pot synthesis of 4H-pyrans. Monatsh Chem 136:727-731

163. Kuthan J (1995) New developments in the chemistry of pyrans. Adv Heterocycl Chem 62:19-135

164. Hatakeyama S, Ochi N, Numata H, Takano S (1988) A new route to substituted 3-methoxycarbonyldihydropyrans: enantioselective synthesis of (-)-methyl elenolate. Chem Commun 1988:1202-1204

165. Cingolant GM, Pigini M (1969) Research in the field of antiviral compounds. Mannich bases of 3-hydroxycoumarin. J Med Chem 12:531-532

166. Peng $Y$, Song $G$, Huang $F$ (2005) Tetramethylguanidine-[bmim] $\left[\mathrm{BF}_{4}\right]$. An efficient and recyclable catalytic system for one-pot synthesis of $4 H$-pyrans. Monatsh fur Chem 136:727-731

167. Consorti CS, Ebeling G, Dupont J (2002) Carbonylation of alkynols catalyzed by $\mathrm{Pd}(\mathrm{II}) / 2-\mathrm{PyPPh}_{2}$ dissolved in organic solvents and in ionic liquids: a facile entry to a-methylene $\gamma$-and $\delta$-lactones. Tetrahedron Lett 43:753-755

168. Dupont J, de Souza RF, Suarez PAZ (2002) Ionic liquid (molten salt) phase organometallic catalysis. Chem Rev 102:3667-3692

169. Zhong W, Wang G, Chen K (2012) Unexpected tandem reaction of new type Morita-Baylis-Hillman adducts promoted by [hmim] $\mathrm{HSO}_{4} / \mathrm{NaNO}_{3}$ system. Heterocycles 85:43-56

170. Yoshida J, Ishichi Y, Isoe S (1992) Intramolecular carbon-carbon bond formation by the anodic oxidation of unsaturated. alpha.stannyl heteroatom compounds. Synthesis of fluorine containing heterocyclic compounds. J Am Chem Soc 114:7594-7595

171. Yoshida J, Sugawara M, Tatsumi M, Kise N (1998) Electrooxidative inter- and intramolecular carbon-carbon bond formation using organothio groups as electroauxiliaries. J Org Chem 63:5950-5961

172. Sabitha G, Reddy KB, Bhikshapathi M, Yadav JS (2006) TMSI mediated Prins-type cyclization of ketones with homoallylic and homopropargylic alcohol: synthesis of 2,2-disubstituted-, spirocyclic-4-iodo-tetrahydropyrans and 5,6-dihydro$2 H$-pyrans. Tetrahedron Lett 47:2807-2810

173. Kishi $Y$, Nagura $H$, Inagi S, Fuchigami T (2008) Facile and highly efficient synthesis of fluorinated heterocycles via Prinscyclization in ionic liquid hydrogen fluoride salts. Chem Commun 2008:3876-3878

174. Astarita A, Cermola F, DellaGreca M, lesce MR, Previtera L, Rubino M (2009) Photooxygenation of furans in water and ionic liquidsolutions. Green Chem 11:2030-2033

175. Banerjee $B(2017)[b m i m] B_{4}$ : a versatile ionic liquid for the synthesis of diverse bioactive heterocycles. Chem Select 2(27):8362-8376

176. Galeffi C, Casinovi CG, Marini-Bettolo GB (1965) Synthesis of centrolobine. Gazz Chim Ital 95:95-100

177. Craveiro AA, Prado AC, Gottlie OR, de Albuquerque PCW (1970) Diarylheptanoids of centrolobium species. Phytochemistry 9:1869-1875
178. Tokuyama H, Makido T, Ueda T, Fukuyama T (2002) One-pot claisen rearrangement with $n$-butyl vinyl ether. Synth Commun 32:869-873

179. Colobert F, Mazery RD, Solladie G, Carreno MC (2002) First enantioselective total synthesis of (-)-centrolobine. Org Lett 4:1723-1725

180. Marumoto S, Jaber JJ, Vitale JP, Rychnovsky SD (2002) Synthesis of (-)-centrolobine by Prins cyclizations that avoid racemization. Org Lett 4:3919-3922

181. Carreno MC, Mazery RD, Urbano A, Colobert F, Solladi'e G (2003) Reductive cyclizations of hydroxysulfinyl ketones: enantioselective access to tetrahydropyran and tetrahydrofuran derivatives. J Org Chem 68:7779-7787

182. Evans PA, Cui J, Gharpure SJ (2003) Stereoselective construction of cis-2,6-disubstituted tetrahydropyrans via the reductive etherification of $\delta$-trialkylsilyloxy substituted ketones: total synthesis of (-)-centrolobine. Org Lett 5:3883-3885

183. Lee E, Kimand HJ, Jang WS (2004) Stereoselective synthesis of (-)-centrolobine. Bull Korean Chem Soc 25:1609-1610

184. Boulard L, BouzBouz S, Cossy J, Franck X, Figadere B (2004) Two successive one-pot reactions leading to the expeditious synthesis of (-)-centrolobine. Tetrahedron Lett 45:6603-6605

185. Clarke PA, Martin WHC (2004) An expedient synthesis of $( \pm)$-centrolobine. Tetrahedron Lett 45:9061-9063

186. Chan K-P, Loh T-P (2005) Prins cyclizations in silyl additives with suppression of epimerization: versatile tool in the synthesis of the tetrahydropyran backbone of natural products. Org Lett 7:4491-4494

187. Clarke PA, Martin WHC (2005) Exploiting the MaitlandJapp reaction: a synthesis of $( \pm)$-centrolobine. Tetrahedron 61:5433-5438

188. Jennings MP, Clemens RT (2005) Total synthesis of (-)-centrolobine: $\beta$ - $C$-glycoside formation via a tandem Grignard addition and stereoselective hemi-ketal reduction. Tetrahedron Lett 46:2021-2024

189. Chandrasekhar S, Prakash SJ, Shyamsunder T (2005) Asymmetric synthesis of the pyran antibiotic (-)-centrolobine. Tetrahedron Lett 46:6651-6653

190. Bohrsch V, Blechert S (2006) A concise synthesis of (-)-centrolobine via a diastereoselective ring rearrangement metathesis-isomerisation sequence. Chem Commun 37:1968-1970

191. Lee C-HA, Loh T-P (2006) Suppression of epimerization due to selectivity leakage: an application towards the total synthesis of (-)-centrolobine. Tetrahedron Lett 47:1641-1644

192. Prasad KR, Anbarasan P (2007) Stereoselective formal synthesis of (-)-centrolobine. Tetrahedron 63:1089

193. Washio T, Yamaguchi R, Abe T, Nambu H, Anada M, Hashimoto $S$ (2007) Asymmetric syntheses of diarylheptanoid natural products, (-)-centrolobine and (-)-de-O-methylcentrolobine via hetero-Diels-Alder reaction catalyzed by dirhodium(II) tetrakis[( $R)$-3-(benzene-fused-phthalimido)-2-piperidinonate]. Tetrahedron 63:12037-12046

194. Dziedzic M, Furman B (2009) An efficient approach to the stereoselective synthesis of 2,6-disubstituted dihydropyrans via stannyl-Prins cyclization. Tetrahedron Lett 50:1086-1086

195. Takeuchi T, Matsuhashi M, Nakata T (2008) Total synthesis of (-)-centrolobine. Tetrahedron Lett 49:6462-6465

196. Chazadaj W, Kowalczyk R, Jurczak J (2010) Enantioselective construction of cis-2,6-disubstituted dihydropyrans: total synthesis of (-)-centrolobine. J Org Chem 75:1740-1743

197. Jeong Y, Kim D-Y, Choi Y, Ryu J-S (2011) Intramolecular hydroalkoxylation in Brønsted acidic ionic liquids and its application to the synthesis of $( \pm)$-centrolobine. Org Biomol Chem 9:374-378 
198. Walton T (1999) Room-temperature ionic liquids. Solvents for synthesis and catalysis. Chem Rev 99:2071-2083

199. Walden $P$ (1914) Molecular weights and electrical conductivity of several fused salts. Bull Acad Imper Sci (St. Petersburg) 1800:405-422

200. Sugden S, Wilkins H (1929) CLXVII.-The parachor and chemical constitution. Part XII. Fused metals and salts. J Chem Soc 1929:1291-1298

201. Ahmed SK, Parveen A (2010) A novel synthesis and antimicrobial activity of flavanone using environmental friendly catalyst $\mathrm{H}\left[\right.$ bimBF $\left._{4}\right]$. Res J Pharm Biol Chem 1:809-815

202. Seijas J, Vazquez-Tato M, Carballido-Reboredo R (2005) Solventfree synthesis of functionalized flavones under microwave irradiation. J Org Chem 70:2855-2858

203. Kabalka GW, Mereddy AR (2005) Microwave-assisted synthesis of functionalized flavones and chromones. Tetrahedron Lett 46:6315-6317

204. Havsteen A (1983) Flavonoids, a class of natural products of high pharmacological potency. Biochem Pharmacol 32:1141-1148

205. Banerji A, Goomer N (1980) A new synthesis of flavones. Synthesis 11:874-875

206. Sharma R, Abdullaha M, Bharate SB (2017) Metal-free ionicliquid-mediated synthesis of benzimidazoles and quinazolin-4(3H)-ones from benzylamines. Asian J Org Chem 6(10):1370-1374

207. Le Floch'h Y, LeFeuvre M (1986) Synthese de dihydroxy phenacylidene triphenylphosphoranes nouveaux precurseurs de composes flavonoides: synthese d'hydroxy- 6 et hydroxy-7 chromones. Tetrahedron Lett. 27:2751-2752

208. Reddy CR, Reddy MD (2014) A metal-free tandem C-C/C-O bond formation approach to diversely functionalized tetrasubstituted furans. J Org Chem 79:106-116

209. Ramprasad J, Nayak N, Dalimba U, Yogeeswari P, Sriram D (2016) Ionic liquid promoted one-pot synthesis of thiazoleimidazo[2,1-b] $[1,3,4]$ thiadiazole hybrids and their antitubercular activity. Med Chem Commun 7(2):338-344

210. Ganguly AK, Mahata PK, Biswas D (2006) Synthesis of oxygen heterocycles. Tetrahedron Lett 47:1347-1349

211. Balogh M, Laszlo P (1993) Organic chemistry using clays. Springer, Berlin

212. Chisen J, Chisen IC, Rafelt JS, Macquarrie DJ, Clark JH (1997) Liquid phase oxidations using novel surface functionalised silica supported metal catalysts. Chem Commun 2203-2204

213. Wen XM, Wang HY, Li SL (2006) Aqueous [bmim] $\left[\mathrm{BF}_{4}\right]$ as green solvent in microwave-assisted organic reactions: clean synthesis of $1 \mathrm{H}$-benzo[f]chromene derivatives. J Chem Res (S) 3:776-778

214. Sun L, Pei W (2007) Researches on a novel method for fluorination of halopyridazine derivatives in ionic liquid. Chin J Chem 25:1005-1007

215. Sarda SR, Pathan MY, Paike VV, Pachmase PR, Jadhav WN, Pawar RP (2006) A facile synthesis of flavones using recyclable ionic liquid under microwave irradiation. Arkivoc XVl:43-48

216. Valizadeh H, Vaghefi S (2009) One-pot Wittig and Knoevenagel reactions in ionic liquid as convenient methods for the synthesis of coumarin derivatives. Synth Commun 39:1666-1678

217. Babu NS, Pasha N, Venkateswara Rao KT, Sai Prasad PS, Lingaiah $\mathrm{N}$ (2008) A heterogeneous strong basic $\mathrm{Mg} / \mathrm{La}$ mixed oxide catalyst for efficient synthesis of polyfunctionalized pyrans. Tetrahedron Lett 49:2730-2733

218. Zhang M-M, Lu L, Zhou Y-J, Wang X-S (2012) lodine-catalyzed synthesis of pyrrolo[1,2-a]quinazoline-3a-carboxylic acid derivatives in ionic liquids. Res Chem Intermed 52:12897-12905

219. Pechmann $\mathrm{H}$ (1884) Neue bildungsweise der cumarine. Chem Ber 17:929-936
220. Simmonis $H$, Remmert $P$ (1914) Eine neue flavon-synthese. Chem Ber 47:2229-2233

221. Sethna SM, Shah NM, Shah RC (1938) Aluminium chloride, a new reagent for the condensation of $\beta$-ketonic esters with phenols. Part I. The condensations of methyl $\beta$-resorcylic acid, and resacetophenone with ethyl acetoacetate. J Chem Soc 1938:228-232

222. Woods LL, Sapp J (1962) A new one-step synthesis of substituted coumarins. J Org Chem 27:3703-3705

223. Upadhyay KK, Mishra RK, Kumar A (2008) A convenient synthesis of some coumarin derivatives using $\mathrm{SnCl}_{2}-\mathrm{H}_{2} \mathrm{O}$ as catalyst. Catal Lett 121:118-120

224. Raju G, Srinivas R, Reddy MD, Reddy CR, Nagesh N (2014) Studies on non-covalent interaction of coumarin attached pyrimidine and 1-methyl indole 1,2,3 triazole analogues with intermolecular telomeric G-quadruplex DNA using ESI-MS and spectroscopy. Nucleosides Nucleotides Nucleic Acids 33:489-506

225. Kokare ND, Sangshetti JN, Shinde DB (2007) Oxalic acid catalysed solvent-free one pot synthesis of coumarins. Chin Chem Lett 18:1309-1312

226. Dabiri M, Baghbanzadeh M, Kiani S, Vakilzadeh Y (2007) Alum $\left(\mathrm{KAl}\left(\mathrm{SO}_{4}\right)_{2} \cdot \mathrm{H}_{2} \mathrm{O}\right)$ catalyzed one-pot synthesis of coumarins under solvent-free conditions. Monatsh Chem 137:997-999

227. Shirini F, Marjani K, Nahzomi HT, Zolfigol MA (2007) Silica triflate as an efficient reagent for the solvent-free synthesis of coumarins. Chin Chem Lett 18:909-911

228. Prajapati D, Gohain M (2007) lodine a simple, effective and inexpensive catalyst for the synthesis of substituted coumarins. Catal Lett 119:59-63

229. Potdar MK, Rasakar MS, Mohile SS, Salunkhe MM (2005) Convenient and efficient protocols for coumarin synthesis via Pechmann condensation in neutral ionic liquids. J Mol Catal A Chem 235:249-252

230. Potdar MK, Mohile SS, Salunkhe M (2001) Coumarin synthesis via Pechmann condensation in Lewis acidic chloroaluminate ionic liquid. Tetrahedron Lett 42:9285-9287

231. Gu Y, Zhang J, Duan Z, Deng Y (2005) Pechmann reaction in non-chloroaluminate acidic ionic liquid under solvent-free conditions. Adv Synth Catal 347:512-516

232. Dong F, Jian C, Kai G, Qunrong S, Zuliang L (2008) Synthesis of coumarins via Pechmann reaction in water catalyzed by acyclic acidic ionic liquids. Catal Lett 121:255-259

233. Sing V, Kaur S, Sapehiyia V, Singh J, Kad GL (2005) Microwave accelerated preparation of [bmim] $\left[\mathrm{HSO}_{4}\right]$ ionic liquid: an acid catalyst for improved synthesis of coumarins. Catal Commun 6:57-60

234. Hafez EAA, Elnagdi MH (1987) Nitriles in heterocyclic synthesis: novel synthesis of benzo[c]coumarin and of benzo[c] pyrano[3,2-c]quinoline derivatives. Heterocycles 26:903-907

235. Jiang ZQ, Ji SJ, Lu J, Yang JM (2005) A mild and efficient synthesis of 5-oxo-5,6,7,8-tetrahydro-4H-benzo[b]pyran derivatives in room temperature ionic liquids. Chin J Chem 23:1085-1089

236. Fang D, Zhang HB, Liu ZL (2010) Synthesis of $4 H$-benzopyrans catalyzed by acyclic acidic ionic liquids in aqueous media. $J$ Heterocycl Chem 47:63-67

237. Kidwai M, Saxena S (2005) Aqua mediated synthesis of substituted 2-amino-4H-chromenes and in vitro study as antibacterial agents. Bioorg Med Chem Lett 15:4295-4298

238. Shestopalov AM, Niazimbetova ZI, Evans DH (1999) Synthesis of 2-amino-4-aryl-3-cyano-6-methyl-5-ethoxycarbonyl4H-pyrans. Heterocycles 51:1101-1107

239. Bloxham J, Dell CP, Smith CW (1994) Preparation of some new benzylidenemalononitriles by an SNAr reaction: application to naphtho[1,2-b]pyran synthesis. Heterocycles 38:399-408 
240. Zhuang QY, Rong LC, Shi DQ (2003) Synthesis and crystal structure of substituted naphthopyran. Chin J Org Chem 23:671-673

241. Zhou Z-Z, Ji F-Q, Cao M, Yang G-F (2006) An efficient intramolecular Stetter reaction in room temperature ionic liquids promoted by microwave irradiation. Adv Synth Catal 348:1826-1830

242. Patil SG, Bagul RR, Swami MS, Hallale SN, Kamble VM (2011) Basic ionic liquid promoted one-step synthesis of 2-alkylsubstituted chromanones. J Chem Pharm Res 3:457-463

243. Ranu BC, Jana R (2006) Ionic liquid as catalyst and reaction medium - a simple, efficient and green procedure for Knoevenagel condensation of aliphatic and aromatic carbonyl compounds using a task-specific basic ionic liquid. Eur J Org Chem 2006:3767-3770

244. Hajipour AR, Rafiee $F$ (2009) Basic ionic liquids. A short review. $J$ Iran Chem Soc 6:647-678

245. Su C, Chen Z-C, Zhen Q-G (2003) Organic reactions in ionic liquids: Knoevenagel condensation catalyzed by ethylenediammonium diacetate. Synthesis 2003:555-559

246. Sakirolla R, Krishnaji T, Yaeghoobi M, Rahman NA (2018) Di-cationic ionic liquid catalyzed synthesis of 1,5-benzothiazepines. Asian J Chem 30(1):107-115

247. Ranu BC, Banerjee S, Roy S (2008) A task specific basic ionic liquid, [bmim]OH-promoted efficient, green and one-pot synthesis of tetrahydrobenzo[b]pyran derivatives. Indian J Chem Sect B Org Chem Incl Med Chem 47:1108-1112

248. Liu X-H, Fan J-C, Liu Y, Shang Z-C (2008) L-Proline as an efficient and reusable promoter for the synthesis of coumarins in ionic liquid. J Zhejiang Univ Sci B 9:990-995

249. Ciganek $\mathrm{E}$ (1995) Esters of 2,3-dihydro-3-oxobenzofuran-2-acetic acid and 3,4-dihydro-4-oxo-2H-1-benzopyran-3-acetic acid by intramolecular Stetter reactions. Synthesis 10:1311-1314

250. Enders D, Breuer K, Runsink J, Teles JH (1996) The first asymmetric intramolecular Stetter reaction. Helv Chim Acta 79:1899-1902

251. Yang Q, Alper H (2010) Synthesis of chromones via palladiumcatalyzed ligand-free cyclocarbonylation of o-iodophenols with terminal acetylenes in phosphonium salt ionic liquids. J Org Chem 75:948-950

252. Song CE, Jung D-U, Choung SY, Roh EJ, Lee S-G (2004) Dramatic enhancement of catalytic activity in an ionic liquid: highly practical Friedel-Crafts alkenylation of arenes with alkynes catalyzed by metal triflates. Angew Chem 116(45):6309-6311

253. Baker M (1933) Molecular rearrangement of some o-acyloxyacetophenones and the mechanism of the production of 3-acylchromones. J Chem Soc 1933:1381-1389

254. Mahal HS, Venkatraman K (1933) A synthesis of flavones at room temperature. Curr Sci 4:214-215

255. Bhosale RS, Sarda SR, Giram RP, Raut DS, Parwe SP, Ardhapure SS, Pawar RP (2009) lonic liquid promoted expeditious synthesis of flavones. J Iran Chem Soc 6:519-522

256. Zhang XY, Li YZ, Fan XS, Qu GR, Hu XY, Wang J (2006) Multicomponent reaction in ionic liquid: a novel and green synthesis of 1, 4-dihydropyridme derivatives. Chin Chem Lett 17:150-152

257. Tu S, Zhu X, Zhang J, Xu J, Zhang Y, Wang Q, Jia R, Jiang B, Zhang J, Yao C (2006) New potential biologically active compounds: design and an efficient synthesis of $\mathrm{N}$-substituted 4-aryl4,6,7,8-tetrahydroquinoline-2,5(1H,3H)diones under microwave irradiation. Bioorg Med Chem Lett 16:2925-2928

258. Khurana JM, Kumar S (2010) lonic liquid: an efficient and recyclable medium for the synthesis of octahydroquinazolinone and biscoumarin derivatives. Monatsh Chem 141(5):561-564
259. Kaur N, Aditi Kishore D (2016) A facile synthesis of face ' $D$ ' quinolino annulated benzazepinone analogues with its quinoline framework appended to oxadiazole, triazole and pyrazole heterocycles. J Heterocycl Chem 53:457-460

260. Adams DR, Bhatnagar SP (1977) The Prins reaction. Synthesis 10:661-672

261. Arundale $E$, Mikeska LA (1952) The olefin-aldehyde condensation. The Prins reaction. Chem Rev 51:505-555

262. Nicolaou KC, Daines RA, Ogawa Y, Chakraborty TK (1988) Total synthesis of amphotericin B. 3. The final stages. J Am Chem Soc 110:4696-4705

263. Rychnovsky SD, Griesegraber G, Kim J (1994) Rapid construction of the roflamycoin system. J Am Chem Soc 116:2621-2622

264. Koichi M, Masaki S (1996) Prins cyclization to tetrahydrofuran units of polyether antibiotics: remarkable siloxy effect for stereocontrolled cyclization. Tetrahedron 52:7287-7296

265. Rychnovsky SD, Yang G, Hu Y, Khiere UR (1997) Prins desymmetrization of a C2-symmetric diol: application to the synthesis of 17-deoxyroflamycoin. J Org Chem 62:3022-3023

266. Delmas M, Gaset A (1980) Selective synthesis of 4-aryl-1,3-dioxanes from arylalkenes and paraformaldehyde using an ion exchange resin as catalyst; extension to natural compounds. Synthesis 11:871-872

267. Zarnegar Z, Safari J (2016) Heterogenization of an imidazolium ionic liquid based on magnetic carbon nanotubes as a novel organocatalyst for the synthesis of 2-amino-chromenes via a microwave-assisted multicomponent strategy. New J Chem 40:7986-7995

268. Pathak AK, Ameta C, Ameta R, Punjabi PB (2016) Microwaveassisted organic synthesis in ionic liquids. J Heterocycl Chem 53(6):1697-1705

269. Ding $M$, Guo $H(2016)$ lonic liquid catalyzed one-pot synthesis of $2 \mathrm{H}$-pyridazino[1,2-a]indazole-1,6,9(11H)-triones via threecomponent reaction under solvent-free conditions. J Heterocycl Chem 53(6):2061-2065

270. Chandrasekhar S, Reddy BVS (1998) First $\mathrm{TaCl}_{5}-\mathrm{SiO}_{2}$ catalyzed Prins reaction: comparative study of conventional heating vs microwave irradiation. Synlett 8:851-852

271. Bach T, Lobel J (2002) Selective Prins reaction of styrenes and formaldehyde catalyzed by 2,6-di-tert-butylphenoxy(difluoro) borane. Synthesis 2002:2521-2526

272. Yadav JS, Reddy BVS, Bhaishya G (2003) InBr 3-[bmim]PF6: a novel and recyclable catalytic system for the synthesis of 1,3-dioxane derivatives. Green Chem 5:264-266

273. Tateiwa J, Kimura A, Takasuka M, Uemura S (1997) Metal cationexchangedmontmorillonite( $\mathrm{M}^{\mathrm{n}+}$-mont)-catalysedcarbonyl-ene reactions. J Chem Soc Perkin Trans 1997:2169-2174

274. Aggarwal VK, Vennall GP, Davey PN, Newman C (1998) Scandium trifluoromethaneslfonate, an efficient catalyst for the intermolecular carbonyl-ene reaction and the intramolecular cyclisation of citronellal. Tetrahedron Lett 39:1997-2000

275. Filloux CM, Lathrop SP, Rovis T (2010) Multicatalytic, asymmetric Michael/Stetter reaction of salicylaldehydes and activated alkynes. Proc Natl Acad Sci 107:20666-20671

Publisher's Note Springer Nature remains neutral with regard to jurisdictional claims in published maps and institutional affiliations. 